University of South Carolina

Scholar Commons

The Operation of Supervisory Colleges in EU Banking Supervision: A Case Study of Soft Law Becoming Hard Law

Duncan E. Alford

Follow this and additional works at: https://scholarcommons.sc.edu/law_facpub

Part of the Banking and Finance Law Commons, European Law Commons, and the International Law Commons 


\title{
The Operation of Supervisory Colleges in EU Banking Supervision: A Case Study of Soft Law Becoming Hard Law
}

\author{
DUNCAN AlForD*
}

The concept of soft law is not easily defined.' One commentator defines soft law as "all those social rules generated by States or other subjects of international law which are not legally binding but which are nevertheless of special legal relevance." 2 Another commentator defines soft law as "a set of written, advisory prescriptions." 3 Soft law is not a contract between sovereign states similar to a treaty. ${ }^{4}$ Under soft law, there are no "mutually agreed obligations" among the parties.5 Soft law occasionally becomes domestic law and its content has been used as an argument for the reform of national laws and rules. ${ }^{6}$

In this paper, I consider the case of supervisory cooperation among international bank regulators where voluntary cooperation (soft law) over a period of fifty years has become hard law (regulations and directives) within the European Union. Driven by major international bank failures or financial crises, international standards for prudential supervisory cooperation among bank regulators have steadily developed and become more precise and defined since the early 1970 s, resulting in the creation of a supranational bank supervisor, the Single Supervisory Mechanism, part of the European Central Bank. ${ }^{7}$

* Duncan Alford, Associate Dean, Director of the Law Library and Professor of Law. J.D. with Honors, University of North Carolina at Chapel Hill. B.A with High Distinction in Economics and French, University of Virginia. M.L.I.S., University of South Carolina. Professor Alford would like to thank Tim Lorrick for his excellent research assistance on this article and also the participants in the conference on The Use of Soft Law by National Courts and Public Autborities: An EU-Cbina Comparison beld at Peking University School of Transnational Law in Shenzhen, China, on November 13, 2019.

1. Daniel Thürer, Soft Law, in Max Planck Encyclopedia of Public Interinational LAW $§ 3$, II 8 (Rüdiger Wolfrum ed., 2015).

2. $I d$.

3. Abraitam L. Newman \& Elliot Posner, Voluntary Disruptions: International Soft Law, Finance, and Power 15 (2018).

4. Id. at 16 .

5. Id. at 17 .

6. Id. at 36 .

7. NFwman \& Posner, supra note 3, at 77. 


\section{Basel Committee Supervision}

The Basel Committee on Banking Supervision, based at the Bank for International Settlements in Basel, Switzerland, has taken the lead on developing international bank supervisory standards. ${ }^{8}$ Since the 1970 s, the Basel Committee, through its issuance of various standards for bank supervision, has attempted to improve supervisory cooperation and reduce systemic risk in the financial system. ${ }^{9}$ The collapse of the Herstatt Bank in Germany in 1974 led to the creation of the Basel Committee and the issuance of the Committee's first agreement on bank supervision, known as the Basel Concordat, in 1975.10 Due to its fraudulent bookkeeping practices, the Herstatt Bank failed and other German banks were unable to bail it out." Legal claims against the Herstatt Bank were eventually settled.12 Most of the international operations of the bank were conducted at its head office in Germany. ${ }^{13}$ While Herstatt's assets were mainly domestic, the bank also had significant foreign creditors. ${ }^{14}$ The resolution of the bank's failure-particularly the incomplete satisfaction of foreign creditors' claims - set a negative precedent for the settlement of international financial crises and demonstrated the need for greater international supervisory cooperation. 15

Organized in 1975,16 the Basel Committee's members consisted of banking regulators from eleven major industrialized nations and

8. Joseph J. Norton, The Multidimensions of the Convergence Processes Regarding the Prudential Supervision of International Banking Activities-The Impact of the Basel Supervisors Committee's Efforts Upon, Witbin and Without the European Community, in FESTSCHRIFT IN HONOR OF SIR JOSEPH Gold 249, 259-60 (Werner F. Ebke \& Joseph J. Norton eds., 1990) [hereinafter Norton, Multidimensions].

9. Id. at 261.

10. Richard C. Williams et al., International Capital Markets: Recent Developments and ShortTerm Prospects (Int'l Monetary Fund Occasional Paper No. 7, Aug. 1981) 29-32, https:// www.elibrary.imf.org/doc/IMF084/03671-9781451981681/03671-9781451981681/Other_for mats/Source_PDF/03671-9781463986964.pdf [https://perma.cc/EY2U-6WYR]. The original Concordat was not released to the public until March 1981. See id. at 29.

11. Ulrich Hess, The Banco Ambrosiano Collapse and the Luxury of National Lenders of Last Resort with International Responsibilities, 22 N.Y.U. J. INT'L L. \& PoL. 181, 185-86 (1990). See generally Joseph D. Becker, International Insolvency: The Case of Herstatt, 62 A.B.A. J. 1290 (1976) (giving a full account of the Herstatt failure). In addition, the London branch of the Franklin National Bank suffered severe losses in the early 1970s, for which the Federal Reserve compensated with liquidity support. Franklin National Bank eventually failed anyway, illustrating the confusion of supervisory responsibilities over international banks. See Hess, supra note 11, at 186-87.

12. West German banks received 45 percent, foreign banks received 55 percent, and other creditors received 65 percent of their respective claims. Hess, supra note 11, at 186.

13. See id.

14. Id.

15. Id.

16. Richard Dale, The Regulation of International Banking 172 (1986); see also Ethan B. Kapstein, Revolving the Regulator's Dilemma: International Coordination of Banking Regulations, 43 INr'L ORG. 323, 329 (1989); Joseph J. Norton, The Work of the Basel Supervisors Committee on Bank Capital Adequacy and the Fuly 1988 Report on International Convergence of 
Luxembourg. ${ }^{17}$ The purpose of the Committee was to provide "regular cooperation between its member countries on banking supervisory matters." 18 The Committee hoped to encourage the convergence of banking regulation to a common approach through the issuance of guidelines developed by consensus among its members; thus, it sought to harmonize the banking laws of its member nations indirectly. ${ }^{19}$ While the Basel Committee had no legal enforcement power itself, it encouraged member nations to abide by these regulatory guidelines and to use whatever authority they possess to enact and enforce them. ${ }^{20}$

\section{Basel Concordat of $\mathbf{1 9 7 5}$}

As a result of the Herstatt failure and the subsequent confusion it caused over the settlement of the bank's liabilities, the Basel Committee set as its first task the establishment of an agreement on the respective roles of home country supervisors to ensure that all international financial institutions are supervised.21 The Committee fulfilled this task by issuing the Basel Concordat, 22 a statement of principles delineating the supervisory responsibilities of home and host banking regulators over international banks. ${ }^{23}$ The Committee entitled the document a "concordat" to indicate that the agreement did not have the legal force of a treaty. ${ }^{24}$ Rather, the Concordat was a set of guidelines on bank supervision reached by consensus among banking regulators from many nations. 25

Capital Measurement and Capital Standards, 23 INT'L L. 245, 246-47 (1989) [hereinafter Norton, International Convergence].

17. Norton, International Convergence supra note 16, at $248 \mathrm{n} .18$; see also Norton, Multidimensions, supra note 8 , at 8 . See generally Marilyn B. Cane \& David A. Barclay, Competitive Inequality: American Banking in the International Arena, 13 B.C. INT'L \& CoMP. L. Rev. 273, 319 n.321 (1990) (providing background on the Bank for International Settlements and the Basel Committee); James V. Hackney \& Kim Leslie Shafer, The Regulation of International Banking: An Assessment of International Institutions, 11 N.C. J. INT'L L. \& Com. REG. 474, 488-89 (1986) (same).

18. Peter Cooke, The Basel "Concordat" on Supervision of Banks' Foreign Establisbments, 39 AusSTNWIRTSCHAFT 151, 151 (1984).

19. Id.

20. See id.

21. See Richard Dale, Someone Must Be in Charge, Fin. Times, July 22, 1991, at 12.

22. Williams et al., supra note 10.

23. The home or parent regulator is the one responsible for supervision in the country where the "parent bank" is headquartered and licensed. The host regulator is the one responsible for supervision in the foreign country where the "parent bank" is operating an establishment. See id. at 30 .

24. M.S. Mendelsohn, New Basel Concordat: Main Deficiency is Intact, Am. Banker, June 16, 1983 , at 2 .

25. See id. The word "concordat" refers to a "public act of agreement" (as opposed to a "contract" between private parties). Id. However, the text of the Concordat was not released to the public for several years following its adoption. Cooke, The Basel "Concordat" on Supervision of Banks' Foreign Establisbments, supra note 18, at 152. 
The objectives of the Concordat were to ensure that the supervision of foreign banks was adequate and that no foreign bank would escape supervision. ${ }^{26}$ A central tenet of the Concordat was the joint responsibility of home and host banking regulators in regulating international banks. ${ }^{27}$ The Concordat set forth five principles:

(1) The supervision of foreign banking establishments should be the joint responsibility of host and parent authorities.

(2) No foreign banking establishment should escape supervision, each country should ensure that foreign banking establishments are supervised, and supervision should be adequate as judged by both host and parent authorities.

(3) The supervision of liquidity should be the primary responsibility of host authorities since foreign establishments generally have to conform to local practices for their liquidity management and must comply with local regulations.

(4) The supervision of solvency of foreign branches should be essentially a matter for the parent authority. In the case of subsidiaries, while primary responsibility lies with the host authority, parent authorities should take account of the exposure of their domestic banks' moral commitment in this regard.

(5) Practical cooperation would be facilitated by transfers of information between host and parent authorities and by the granting of permission for inspections by or on behalf of parent authorities on the territory of the host authority. Every effort should be made to remove any legal restraints (particularly in the field of professional secrecy or national sovereignty) which might hinder these forms of cooperation. ${ }^{28}$

The Concordat had several weaknesses. First, despite the agreement's goal of allocating supervisory responsibility, it left unclear which regulator should act in order to contain a major bank failure.29 Also, designating the host supervisor as the primary regulator of the solvency of a foreign bank subsidiary ran counter to the principle of consolidated supervision used by bank regulators in most industrialized nations. ${ }^{30}$ With these conflicting allocations of responsibility in the Concordat, there was a real danger that

26. Williams et al., supra note 10 , at 29 .

27. Dale, Someone Must Be in Charge, supra note 21, at 12; see also Dale, The Regulation of INTERNATIONAL BANKING, supra note 16, at 172.

28. W. Peter Cooke, Supervising Multinational Banking Organizations: Evolving Tecbniques for Cooperation Among Supervisory Authorities, 3 J. Comp. CoRP. L. \& SEC. REG. 244, 246 (1981) (summarizing the Basel Concordat); see also Richard Dale, Basel Concordat: Lessons from Ambrosiano, BANKer, Sept. 1983, at 55 (same).

29. See Kapstein, supra note 16, at 330.

30. Dale, The Regulation of International Banking, supra note 16 , at 173 . Under consolidated supervision, responsibility for regulating a bank's foreign subsidiaries is shared between host and parent regulators, with the parent supervisor considering all of the assets and liabilities of the bank, wherever located, in order to determine the bank's overall solvency. See id. at 176. See generally Council Directive 83/350 of 13 June 1983 on the Supervision of Credit 
host regulators, following consolidated supervision, would look to parent supervisors to regulate a bank subsidiary's solvency while parent regulators, relying upon the Concordat, would look to the host supervisor to perform this task. ${ }^{31}$

Another weakness of the Concordat was its lack of specific supervisory standards for international bank regulators to employ. ${ }^{32}$ This lack of specific standards created confusion among banking regulators and allowed individual nations to interpret the Concordat as they wished. ${ }^{33}$ Other misconceptions resulted from the Concordat. The most important and potentially dangerous was the mistaken belief that lender of last resort responsibility accompanied supervisory responsibility. ${ }^{34}$ The Committee never intended the Concordat to deal with lender of last resort responsibility. ${ }^{35}$

The financial collapse during the summer of 1982 of the Luxembourg subsidiary of the Banco Ambrosiano, an Italian bank, tested the principles of the Concordat. The Banco Ambrosiano subsidiary in Luxembourg had made $\$ 1.4$ billion worth of imprudent loans to Latin American companies. ${ }^{36}$ As a result, the subsidiary owed nearly $\$ 450$ million to its creditors. ${ }^{37}$ Unable to pay its creditors, the bank and its Luxembourg subsidiary collapsed in July $1982.3^{38}$

Neither the Luxembourg nor the Italian regulators claimed supervisory or lender of last resort responsibility for the bank. ${ }^{39}$ The Italian regulators argued that because they lacked the legal authority to regulate the Luxembourg subsidiary, they bore little or no responsibility for its failure. ${ }^{40}$ In contrast, Luxembourg regulators believed that a subsidiary operating under the same name as its parent bank (as was the case with the Luxembourg subsidiary of Banco Ambrosiano) should have been supported

Institutions on a Consolidated Basis, 1983 O.J. (L 193) 18 (representing the European Community's adoption of consolidated supervision principles).

31. Dale, The Regulation of International Banking, supra note 16, at 173. The "primary motivation" for drafting the Revised Concordat, adopted in 1983, was to "incorporate understandings on applying the principle of consolidated supervision." Cooke, The Basel "Concordat" on Supervision of Banks' Foreign Establishments, supra note 18, at 152-53.

32. Dale, The Regulation of International Banking, supra note 16 , at 173.

33. Id. at 174 .

34. Lender of last resort responsibility refers to the obligation of a central bank or regulator to provide as much liquidity as necessary to a bank in order to meet its obligations to depositors and creditors. Id.

35. Id.; Cooke, The Basel "Concordat" on Supervision of Banks' Foreign Establisbments, supra note 18, at 153-54. The Basel Concordat is silent on this point.

36. Hess, supra note 11 , at 189.

37. Id. at 190 .

38. $I d$. at $189-90$.

39. Dal,e, The Regulation of International Banking, supra note 16 , at 175 . See generally Maximtlian J.B. Hall, Financial Deregulatton: A Comparative Study of Australia and the Unted Kingdom 202 n.32 (1987) (describing the Banco Ambrosiano collapse and its resolution).

40. Dale, The Regulation of International Banking, supra note 16, at 175 . 
either by the parent bank or indirectly by the central bank of the parent bank. ${ }^{41}$ Given that the parent bank of Banco Ambrosiano was headquartered in Italy, Luxembourg regulators believed that the parent bank or the Italian central bank should have supported the Luxembourg subsidiary bank. ${ }^{42}$

\section{Revised Concordat of $\mathbf{1 9 8 3}$}

The Basel Committee responded to the collapse of the Luxembourg subsidiary of Banco Ambrosiano by issuing in May 1983 a reformulation of the Concordat, known as the Revised Concordat. ${ }^{43}$ Even though W. Peter Cooke, chairperson of the Basel Committee, believed that the failure of Banco Ambrosiano was a unique event, 44 the Basel Committee made substantive changes to their international agreement.

The Revised Concordat was not an entirely new agreement, but built upon the 1975 Concordat. ${ }^{45}$ Like its predecessor, it was a non-binding agreement that embodied "recommended guidelines of best practices." 40 Under the Revised Concordat, nations still retained authority to license banks with few restrictions-even banks they were unable to regulate effectively. ${ }^{47}$ Furthermore, there was no incentive for compliance with the Revised Concordant, except for the political pressure or moral authority that bank regulators could exercise on their recalcitrant colleagues. ${ }^{48}$ But with the Revised Concordat, the Basel Committee did attempt to close the supervisory gaps that existed under the Concordat and to address directly the adequacy of supervision of foreign financial institutions. ${ }^{49}$

As with the 1975 Concordat, a primary objective of the Revised Concordat was to ensure that no foreign banking establishment would escape supervision and that each establishment would be supervised

41. See id. at 175, 57. The turmoil resulting from Banco Ambrosiano's failure ended when two settlement agreements were signed: the first between the liquidators of Banco Ambrosiano and the creditors of the Luxembourg holding company (and its foreign subsidiaries); and the second between the creditors of Banco Ambrosiano and the creditors of the Vatican bank. Hess, supra note 11, at 194-95. In the aftermath of the Banco Ambrosiano affair, the Italian Parliament passed a law that required disclosure of the shareholder structure of banks and also passed enabling legislation for the 1983 Council Directive on Supervision. Id. at 199.

42. Hess, supra note 11 , at 191.

43. Revised Basel Concordat on Principles for the Supervision of Banks' Foreign Establishment, July 1983, 22 I.L.M. 900, 901 [hereinafter Revised Concordat]; see also Dale, Someone Must Be in Charge, supra note 21, at 12.

44. Hall, supra note 39 , at 166.

45. See id.; Cooke, The Basel "Concordat" on Supervision of Banks' Foreign Establisbments, supra note 18, at 152; see also Revised Concordat, supra note 43, at 901.

46. Revised Concordat, supra note 43, at 901

47. See Mendelsohn, supra note 24, at 2 (criticizing the Basel Committee for repeating its failure to address the lender of last resort responsibility in the Revised Concordat).

48. See id. (noting that the Revised Concordat remained "no more than an informal agreement").

49. See id. at 1. 
adequately. ${ }^{50}$ The Revised Concordat introduced a "dual key" approach whereby both home and host supervisory authorities assessed the quality of each other's supervision of an international bank. ${ }^{51}$ A bank regulator in a host jurisdiction had to be satisfied that the parent bank was being supervised adequately in the parent jurisdiction, and the parent jurisdiction had to be satisfied that all foreign operations were being supervised adequately by local regulators. ${ }^{52}$ If the host regulator considered the supervision of the parent bank by the parent regulator insufficient, the host regulator had the right to discourage or prohibit the foreign bank from operating within the host jurisdiction, or it could set conditions for the bank's continued operation there. ${ }^{53}$ Likewise, the parent regulator could attempt to extend the jurisdictional reach of its supervision if it did not believe that the host regulator was providing adequate supervision of the operations of the foreign bank; alternatively, it could discourage the parent bank from operating in the host nation. ${ }^{54}$ Using this "dual key" approach, the Committee intended to prevent a "race to the bottom"- the tendency for jurisdictions to relax financial regulation and supervision in order to attract more foreign investment. 55

In the case of the failure of the Luxembourg subsidiary of Banco Ambrosiano, no regulator took responsibility for the supervision of the Luxembourg-based bank. 56 Applying the terms of the Revised Concordat to the situation that existed there, Luxembourg would have had the primary responsibility to supervise the subsidiary, but if the parent regulator (Italy) had not been satisfied with that supervision, it could have tried to step in and regulate the bank. ${ }^{57}$

The Revised Concordat adopted the principle of consolidated supervision, by which the parent regulator monitors the parent bank's risk exposure and capital adequacy based on all the operations of the bank, wherever conducted. 58 Drafters of the Revised Concordat acknowledged that

50. Revised Concordat, supra note 43, at 903.

51. Dale, Someone Must Be in Charge, supra note 21, at 12.

52. Id.; see Revised Concordat, supra note 43, at 903-04. The "dual key" approach is highly dependent on effective communication and active cooperation among host and parent regulators. See id. at 901-02.

53. Revised Concordat, supra note 43, at 903-04; DAIE, THE Regulation OF INTERNAJIONAL BANKING, supra note 16 , at 175. This provision was a concession to U.S. regulatory authorities, whose previous attempts to monitor the status of foreign parent banks with U.S. offices were met with strong resistance from foreign supervisory authorities. Id. at 57 .

54. Revised Concordat, supra note 43, at 903.

55. Dale, Someone Must Be in Charge, supra note 21, at 12.

56. Dale, The Regulation of International Banking, supra note 16, at 176.

57. See Revised Concordat, supra note 43, at 903. The Revised Concordat calls for a concerned parent regulator to extend its supervision in such a manner "to the degree that it is practicable." Id.

58. Id. at 905 . 
adoption of this concept could extend the traditional limits of a parent regulator's supervisory responsibility..$^{59}$

The difficulty of implementing consolidated supervision seemed evident from the drafters' treatment of the supervision of international bank holding companies. ${ }^{60}$ The Revised Concordat designated the host regulator (rather than the parent regulator) as the primary supervisor of subsidiary banks belonging to a bank holding company but failed to designate a primary regulator of the bank holding company. ${ }^{61}$ This would prove to be a very significant gap and was a factor in the subsequent failure of BCCI in 1991.62 As banks expand into new and different lines of business, they tend to develop complex holding company structures. Banco Ambrosiano's attenuated and far-flung corporate structure allowed it to escape effective regulation. ${ }^{63}$ Under the terms set forth in the Revised Concordat, a holding company with independent banks operating in different countries could avoid meaningful regulation because no one regulator had responsibility for the parent's overall health. ${ }^{64}$ Likewise, effective supervision of a holding company with both bank and non-bank subsidiaries also required the cooperation of different regulators. ${ }^{65}$

Overall, the Revised Concordat differed significantly from the 1975 Concordat. ${ }^{66}$ Unlike the 1975 version, it adopted consolidated supervision, an important technique for monitoring the overall risk exposure and capital adequacy of a bank; introduced the "dual key" approach; and explicitly stated that it was not meant to address lender of last resort responsibility. ${ }^{67}$

The Revised Concordat, like its predecessor, also contained some weaknesses. One major problem was the explicit refusal to address the issue of lender of last resort responsibility. ${ }^{68}$ Theoretically, if banking regulators cooperate to prevent bank failures, they should also cooperate in upholding the international banking system when a failure is imminent. The Revised

59. Id.

60. Id.

61. Id. at 904.

62. See Dale, Someone Must Be in Charge, supra note 21, at 12 (pointing out that BCCI's structure was such that it could avoid stringent consolidated supervision under the Revised Concordat).

63. Banco Ambrosiano consisted of a parent bank in Italy and several foreign subsidiaries, including banks located in Peru, Panama, and Luxembourg. See Hess, supra note 11, at 189-90. The Luxembourg subsidiary, Banco Ambrosiano Holding, itself had a Bahamian subsidiary, Banco Ambrosiano Overseas Ltd. See id. at 190.

64. See Revised Concordat, supra note 43, at 904.

65. See id.

66. See id.

67. Id. at 901 .

68. Id. (stating that Revised Concordat does not address lender of last resort responsibility); Mendelsohn, supra note 24, at 2. 
Concordat, however, lacked any statement on what should happen if this supervisory system failed. 69

The Revised Concordat purposely blurred host and parent regulatory responsibilities in order to avoid the pointing of fingers that occurred among regulators after the 1982 failure of Banco Ambrosiano.70 In doing so, however, it also appeared to create problems of overlapping authority and responsibility in cases where one regulator was designated the primary regulator, but another regulator also had a strong interest in maintaining effective supervision over a foreign bank. ${ }^{71}$ This blurring of responsibility created uncertainty for regulators over their supervisory responsibilities. ${ }^{72}$ In theory, the parent regulator ultimately should have responsibility for the safety and soundness of its banks-in all of their forms and establishments, foreign and domestic. ${ }^{73}$ The principle of consolidated supervision allows a parent regulator, in the course of enforcing its own regulations, to approve or disapprove of its banks' foreign operation. ${ }^{74}$ This power would prevent crises in the foreign establishments of its domestic banks while assuring the health of the domestic banks as well. ${ }^{75}$ Despite significant improvements over the original Concordat, the Revised Concordat left gaps in the coordination of international bank regulations.

\section{Minimum Standards for the Supervision of International Banking Groups}

The principles underlying the Revised Concordat were tested in the failure of BCCI in the early 1990s. In a coordinated action on July 5, 1991, regulators in eight nations closed all the BCCI branches located within their jurisdictions. ${ }^{76}$ At the time BCCI had total assets of approximately $\$ 20$ billion and was operating in sixty-nine countries, with the largest concentration of its deposits in the United Kingdom. ${ }^{77}$ Due to the absence

69. David W. Wise, International Prudential Regulation of Commercial Banks, BanK AdmIN., June 1985, at 58, 62. "Just as laws should provide for their own enforcement, supervision should provide for the eventuality that such supervision can fail." Id.

70. Id.

71. See e.g., Revised Concordat, supra note 43, at 906 (stating that the countries in which joint ventures are incorporated-host countries-have primary responsibility for supervising the joint venture, but that the parent regulators of banks that are shareholders in the joint venture cannot ignore supervision of the joint venture).

72. Wise, supra note 69 , at 62 .

73. Id.

74. See id.

75. Id.

76. Max Hall, The BCCI Affair, BANKING WORLD, Sept. 1991, at 8. The eight nations were the Cayman Islands, France, Germany, Luxembourg, Spain, Switzerland, the United Kingdom, and the United States. Id. Indeed, on that day, action to shut down BCCI's activities was taken in more than sixty nations. Id.

77. Statement by J. Virgil Mattingly, Jr., Gen. Counsel, and William Taylor, Staff Director, Division of Banking Supervision and Regulation, Board of Governors of the Federal Reserve System, and E. Gerald Corrigan, President, Federal Reserve Bank of New York, Before the 
of any international law governing the closure of an international bank, local regulators acted under separate national laws. ${ }^{78}$ By July 6, 1991, BCCI offices in eighteen countries either were closed or had their operations restricted. ${ }^{79}$ The closure of BCCI branches continued for several weeks, and by July 29, 1991, forty-four jurisdictions had closed BCCI offices located within their borders. 80

The immediate reason for the closure of BCCI was the Bank of England's receipt of a June 1991 report prepared by Price Waterhouse that detailed massive fraud committed by BCCI's senior managers. ${ }^{81}$ Through the mid1980 s, the treasury operations of BCCI suffered huge losses. Senior managers siphoned off deposits to cover these losses. ${ }^{82}$ If the depositors withdrew their money, then other deposits were diverted to cover the losses. This practice resulted in an endless series of fraudulent transactions. ${ }^{83}$

In response to the failure of $\mathrm{BCCI}$, the Basel Committee issued the Minimum Standards for the Supervision of International Banking Groups. ${ }^{84}$ The Basel Committee reformulated the principles reflected in the Concordat and the Revised Concordat into Minimum Standards for bank supervision. ${ }^{85}$ The main features of the new Minimum Standards are that:

(1) all international banks and banking groups should be supervised by a "home-country" regulator; (2) an international bank should obtain the permission of both the host and home regulators before opening a branch or other banking establishment in a foreign nation; (3) banking regulators should have the right to gather information from international banks; (4) if the minimum standards are not met, a host

Committee on Banking, Finance and Urban Affairs, U.S. House of Representatives, 77 FED. Res. Bull. 902, 905 (Sept. 13, 1991) [hereinafter Mattingly Statement]. BCCI was no longer accepting retail deposits in its U.S. offices because of actions taken previously by U.S. bank regulators. Id. at 907 .

78. Cf. Claire Makin, Learning From BCCI, InstrTutIONAL Inv., Nov. 1991, at 93-95 (discussing various local investigations into BCCI and the lack of overall international accountability). In a 1989 interview, former BCCI chief executive, Swaleh Naqvi, acknowledged that "[b]ecause we do not have a dominant presence in any single country, the full impact of what we are doing is not visible." Id. at 94.

79. Mattingly Statement, supra note 77 , at 903 .

80. Id.

81. Hall, supra note 76, at 8. The Bank of England had commissioned the report under Section 41 of the 1987 Banking Act, which permits the investigation of banks on behalf of depositors. Banking Act (1987), $\$ 41,4$ H^ls. STAT. (4th ed.) 527, 574-76 (U.K.).

82. David Lascelles, A Never-ending Spiral of Fraud, Fin. Times, Oct. 22, 1991, at 32. There are estimates that BCCI raised over $\$ 600$ million in unrecorded deposits. See All Things to All Men, ECONOMIsT, July 27, 1991, at 67, 68 .

83. Lascelles, supra note 82 , at 32.

84. See Minimum Standards for the Supervision of International Banking Groups and Their CrossBorder Establishments, BASEl Comm. ON BANkING SuPERvision (1992), https://www.bis.org/ publ/bcbsc314.pdf [https://perma.cc/9K2P-TXH7] [hereinafter Minimum Standards].

85. See id. The 1990 Supplement to the Revised Concordat concerning "Information flows between banking supervisory authorities" was not made part of the Minimum Standards. Id. at 2. 
regulator may impose restrictive measures against the international bank; and (5) information exchanges between regulators in different nations should continue to be encouraged. ${ }^{86}$

The Minimum Standards specifically state that all international banks should be subject to consolidated supervision by their home regulators. ${ }^{87}$ Consolidated supervision requires that the home-country regulator receive information that can be confirmed as reliable on the global operations of the particular international bank. ${ }^{88}$ This information is then assessed as to the light it sheds on the safety and soundness of the international bank. ${ }^{89}$ Under the Minimum Standards, home-country bank regulators can prevent the creation of corporate affiliations that undermine the application of consolidated supervision or that hinder effective regulation, ${ }^{90}$ and they can prevent the opening of banking establishments in a foreign jurisdiction if, for example, they are not satisfied with that host country's supervision of foreign banks. 91

The host country regulator likewise has the responsibility to ensure that the home-country regulator has the ability to meet these minimum standards. ${ }^{92}$ According to the Minimum Standards, an international bank must receive permission from both its home country and host country regulators before opening a cross-border banking establishment. ${ }^{93}$ In determining whether to approve a foreign operation, the host country regulator can consider the bank's strength of its capital, organization, and operating procedures for risk management. ${ }^{44}$ The approval of any new banking establishment should be contingent upon a multilateral agreement among regulators that each may gather the information necessary for effective home country supervision. 95 That is, regulators should reach a mutual understanding that they can gather information from establishments within each other's jurisdiction. 96

The Minimum Standards make the same allocation of supervisory responsibilities between home country and host country regulators as was set forth in the Revised Concordat, except in cases where the regulators have decided that that allocation is inappropriate. ${ }^{97}$ If a regulator determines that

86. The Minimum Standards use the terms "home-country" and "host-country" in lieu of "parent" and "host." International Panel on Banking Revises Minimum Standards, WALL ST. J., July 7, 1992, at C25.

87. Minimum Standards, supra note 84, at 3.

88. See id.

89. Id.

90. Id. at 3-4.

91. See id.

92. Id. at 2 .

93. Id. at 4 .

94. Id. The home-country regulator, of course, should consider the same factors.

95. Id. at 4-5.

96. Id. at $5-6$.

97. See id. The allocations referred to are found in the Revised Concordat, supra note 43, at 905-08; see also supra text accompanying notes 92-101. 
this allocation is not appropriate in the regulation of a particular bank, then it must reach an explicit agreement with its counterpart on a more appropriate allocation of supervisory responsibility. ${ }^{98}$ In other words, under the Minimum Standards, there can be no evasion of responsibility. 99 In the absence of an agreement to the contrary, the Revised Concordat allocates supervisory responsibilities. 100

In its statement accompanying the issuance of the Minimum Standards, the Basel Committee stated, "[ $\mathrm{t}]$ he minimum standards are designed to provide greater assurances that in the future no international bank can operate without being subject to effective, consolidated supervision."101 The Minimum Standards themselves make clear that consolidated supervision is a vital regulatory principle and that no further debate on its importance is required. 102

Under the new standards, the home country regulator is clearly the primary supervisor of the foreign banking establishments of a bank incorporated in the home country. ${ }^{103}$ According to the new standards, a single bank regulator must exercise primary regulatory authority over an international bank. 104 This prevents any sort of weak collegial regulatory arrangement, similar to the one that attempted to supervise BCCI for several years. ${ }^{105}$

The most important change provided in the new standards is the formalization of the principle that an international bank must receive the permission of both home and host regulators before it can open a foreign banking establishment.106 This double approval for the establishment of a new foreign branch will prevent the finger-pointing that had occurred in the past after a bank failure.107 In approving the foreign banking establishment, the host regulator should be satisfied that the home regulator will supervise the foreign bank on a consolidated basis. ${ }^{108}$ If not satisfied, the host regulator can prevent the foreign bank from opening the branch. ${ }^{109}$

98. Minimum Standards, supra note 84 , at 5 .

99. See also Revised Concordat, supra note 43 , at $903 .^{\circ}$

100. Id. at 901 .

101. Duncan E. Alford, Basel Committee Minimum Standards: International Regulatory Response to the Failure of BCCI, 26 GW J. INT'L \& ECON. 241, 269 (1992).

102. Id.

103. Erik Ipsen, Central Bankers Unveil New Anti-Fraud Rules, INT'L Herald TRIB., July 7, 1992, at 9; see Minimum Standards, supra note 84, at 3.

104. Learning from BCCI, FIN. TIMEs, July 7, 1992, at 18. Specifically, the Minimum Standards state that "[a]ll . . . international banks should be supervised by a home-country authority that capably performs consolidated supervision." Minimum Standards, supra note 84, at 3 .

105. Mattingly Statement, supra note 77, at 917-18. See Section VI for discussion of supervisory colleges.

106. See Minimum Standards, supra note 84, at 4; see also Ipsen, supra note 103, at 9.

107. See Basel Committee on Banking Supervision Issues New Standards to Prevent Fraud, at A-1.

108. See Minimum Standards, supra note 84, at 4; Learning from BCCI, supra note 104, at 18.

109. See Minimum Standards, supra note 84, at 6 (stating that the host-country regulator should prevent creation of a foreign bank establishment when it is dissatisfied with the home-country's supervision). 


\section{Core Principles for Effective Banking Supervision}

Responding to the continued growth of international banking and the need for improved bank supervision, the Basel Committee eventually developed broader, more substantive standards for bank supervision. ${ }^{110}$ Rather than focusing merely on the coordination of international bank supervision, ${ }^{111}$ the Basel Committee provided comprehensive minimum standards for bank supervision when it published the Core Principles in 1997.112

In the 1990s, several prominent bank failures occurred.113 In February 1995, the venerable Barings Bank of London (Barings) failed after a trader in the Singapore operation, Nicholas Leeson, had lost over $\$ 927$ million (U.S.\$ 1.1 billion) in the futures market in Singapore. ${ }^{114}$ Leeson took advantage of his position as both a trader and manager of the settlements operation in Barings' Singapore office to hide his losses from his managers for several years. ${ }^{115}$ By the time these losses were discovered, they exceeded Barings' capital. 116 Despite intense negotiations, the Bank of England refused to support Barings, and the bank was put into receivership in February 1995 and subsequently sold to International Netherlands Group (ING).117

Later in 1995, the Federal Reserve Board revoked the charter of the New York branch of the Daiwa Bank (Daiwa) because of its concealment of over $\$ 1$ billion in unrecorded trading losses incurred in the bond market.118 Daiwa had informed the Japanese Ministry of Finance of this information on August 8, 1995.119 The Ministry of Finance, however, delayed communicating the information to the Federal Reserve Board until September 18, 1995.120 The Federal Reserve promptly issued an order under the Foreign Bank Supervision Enhancement Act closing the Daiwa branch, which wound up its U.S. operations on February 2, 1996.121 The Daiwa closing preceded a 1997 financial crisis that spread across Asia and

110. See Core Principles for Effective Banking Supervision, 37 I.L.M. 405, 410 (1998) (presenting guiding principles for bank supervision).

111. Id. at 406 .

112. Id. at 405 .

113. George Hanc, The Banking Crises of the 1980s and Early 1990s: Summary and Implications, 11 F.D.I.C. Banking Rev. 1, 1 fig.1.1 (1998).

114. Joseph J. Norton \& Christopher D. Olive, Globalization of Financial Risks and International Supervision of Banks and Securities Firms: Lessons from the Barings Debacle, 30 INT'L L. 301, 309 (1996).

115. See id. at 307-09.

116. See id. at $4-5,18$ n.121.

117. See id. at 323.

118. Kristin Leigh Case, The Daiwa Wake-Up Call: The Need for Standards for Banking Supervision, 26 GA. J. INT'L \& COMP. L. 215, 215-16 (1996).

119. Id. at 216.

120. Id. at 217 .

121. Id. at 215 . 
resulted in the closure of many banks and the dramatic decrease in the gross national products of nations such as Thailand, Indonesia, and Malaysia. ${ }^{122}$

During this volatile period, the finance ministers and bank regulators of the G-7 were becoming uneasy about the stability of the international financial system. ${ }^{123}$ At the 1996 G-7 summit in Lyon, France, the leaders (through the Summit Communiqué) requested standard-setting bodies, including the Basel Committee, to draft more comprehensive and detailed financial standards. ${ }^{124}$ The leaders stated in the communique that:

We welcome the work accomplished by the international bodies concerned with banking and securities regulation. Over the year ahead, we should seek to make maximum progress on ... encouraging the adoption of strong prudential standards in emerging economies and increasing cooperation with their supervisory authorities; international financial institutions and bodies should increase their efforts to promote effective supervisory structures in these economies. ${ }^{125}$

The Basel Committee responded to this call by issuing the Core Principles in September 1997, slightly over one year after the G-7's request. ${ }^{126}$

The Core Principles set forth broad guidelines on best practices for bank supervision. ${ }^{127}$ The document did not merely deal with the coordination of supervision of internationally active banks. Instead, its initial twenty-four guidelines provide standards for supervising entire national banking systems from the licensing of banks to their closure due to insolvency.128 Three of the initial twenty-four principles dealt with cross-border banking, which previously had been the focus of the Basel Committee's standard-setting work. ${ }^{129}$ The remainder set forth guidelines for the supervision of banks, even those without international operations. ${ }^{130}$ This document represented a major expansion of the Basel Committee's work on bank supervision.

122. See generally Peter G. Peterson et al., Safeguarding Prosperity in a Global Financial System: The Future of the International Financial Architecture, COUNCLL ON FOREIGN Rels. (Oct. 17, 1999), https://cdn.cfr.org/sites/default/files/report_pdf/Safeguarding_Prosperity.pdf?_ $\mathrm{ga}=2.122280715 .1037029839 .1572708904-1815848409.1572708904$ [https://perma.cc/SL5KLC2M] (discussing a task force implemented to combat the Asian financial crisis); Peter Kenen, The New International Financial Architecture: Reconstruction, Renovation or Minor Repair?, 5 INT'L J. FIN. \& ECON. 1, 7-9 (2000) (exploring Thailand's bank failures).

123. Lyon Summit Communique: Making a Success of Globalization for the Benefit of All art. 1, II 15, June 28, 1996, 7 U.S. Dep'T STATe DisPatch [hereinafter Lyon Communique].

124. See id. at art. 1, II 10-11.

125. Id. at art. 1, I 11.

126. See Denver Summit of the Eight, Final Report to the G-7 Heads of State and Government on Promoting Financial Stability 1 (1997), http://www.g7.utoronto.ca/summit/1997denver/ finanrpt.htm [https://perma.cc/UE5E-B5C3].

127. Core Principles for Effective Banking Supervision, supra note 110, at 405 (presenting guiding principles for bank supervision).

128. See id. at 4-7.

129. Id. at $41-43$.

130. See id. at 4-7. 
The current twenty-nine principles are divided into two subject categories: powers, responsibilities, and functions of supervisors (Principles 1 to 13) and prudential regulations and requirements (Principles 14 to 29). ${ }^{131}$ Three principles relate to supervisory cooperation: Principles 3, 12, and 13.132

Principle 3 (Cooperation and consolidation) states that laws, regulations, or other arrangements provide a framework for cooperation and collaboration with relevant domestic authorities and foreign supervisors. ${ }^{133}$ These arrangements reflect the need to protect confidential information.

Principle 12 (Consolidated Supervision) states that an essential element of banking supervision is that the supervisor supervises the banking group on a consolidated basis, adequately monitoring and, as appropriate, applying prudential standards to all aspects of the business conducted by the banking group worldwide. ${ }^{34}$

Principle 13 (Home-host Relationships) states that home and host supervisors of cross-border banking groups share information and cooperate for effective supervision of the group and group entities, and effective handling of crisis situations. 135 Supervisors require the local operations of foreign banks to be conducted to the same standards as those required of domestic banks. 136

In effect, the Basel Committee incorporated the Minimum Standards into the Core Principles.

\section{The Great Recession and Greater Use of Supervisory Colleges}

Supervisory colleges are "permanent but flexible coordination structures that bring together the competent authorities involved in supervising crossborder banking groups." 137 Their purpose is

to more effectively supervise G-SIBs [global systemically important banks] and other internationally active banking groups by strengthening information-sharing among supervisors, helping the development of a common understanding of risk in banking groups, promoting a shared agenda for addressing risks and vulnerabilities, and providing a platform

131. Id. at 14 .

132. Id. at $9,13,32,41$.

133. See id. at $9,13$.

134. Id. at 32 .

135. Id. at 41 .

136. Id. at $10-11$.

137. Annual Report on Supervisory Activities, Eur. Centrat. Bank 64 (2017), https:// www.bankingsupervision.europa.eu/press/publications/annual-report/pdf/ssm.ar2017.en.pdf [https://perma.cc/9BK6-YEF4]. 
for communicating key supervisory messages among college members. ${ }^{138}$

Supervisory colleges play a valuable role in the supervision of internationally active banks, particularly the largest global banks.

The Great Recession of 2007-2008 provided the impetus for deepened supervisory cooperation. To address the financial crisis, the leaders of the G20 nations met in Washington, D.C., in November 2008.139 The G20 in its communique at the end of this summit on financial markets and the world economy noted the importance of the use of colleges of supervisors to enhance supervisory cooperation related to global banks. ${ }^{140}$ This joint communiqué stated that by March 31, 2009, "supervisors should collaborate to establish supervisory colleges for all major cross-border financial institutions, as part of the efforts to strengthen the surveillance of crossborder firms. Major global banks should meet regularly with their supervisory college for comprehensive discussions of the firm's activities and assessments of the risks it faces." 141 The countries at the Washington Summit in 2008 agreed to meet again in London by April 30, 2009 to review the implementation of these principles and decisions. ${ }^{142}$

During the London Summit on April 2, 2009, G20 leaders themselves agreed "to establish the much greater consistency and systemic cooperation between countries, and the framework of internationally agreed high standards, that a global financial system requires." 143 The G20 leaders affirmed their finance ministers' recommendation and established the Financial Stability Board, as successor to the Financial Stability Forum,144

138. Progress Report on the Implementation of the Principles for Effective Supervisory Colleges, BASEL COMm. ON Banking Supervision 1 (July 2015), https://www.bis.org/bcbs/publ/d329.pdf [https://perma.cc/6E2C-F34H]. A G-SIB is a global systemically important bank as defined by the Financial Stability Board. Id. at 2.

139. G20 Leaders, Declaration Summit on Financial Markets and the World Economy 1 (2008), https://www.fsb.org/wp-content/uploads/g20_leaders_declaration_washington_2008.pdf

[https://perma.cc/XYL6-NCG8].

140. Id. at 4 .

141. Id. at 1 .

142. $I d$.

143. The Global Plan for Recovery and Reform: The Communique from the London Summit, 15 L. \& Bus. Rev. Am. 703, 705 (2009).

144. Previously in 2008, in two separate reports, the Financial Stability Forum had recommended the expanded use of colleges of supervisors. In its April 2008 report, the Financial Stability Forum recommended that all global banks be supervised by a college of supervisors and that supervisors should build on existing examples of supervisory colleges both in the Basel II framework and in regional arrangements, such as within the European Union. The purpose of the colleges is to enhance cooperation on supervisory issues and each college would be organized differently depending on the structure of the global bank it was supervising. Similarly, the forum recommended that by 2009 the colleges should conduct an exercise to draw lessons about best practices of colleges of supervisors. Financial Stability Forum, Report of the Financial Stability Forum on Enbancing Market and Institutional Resilience 42 (Apr. 7, 2008), http://www.financialstabilityboard.org/publications/r_0804.pdf [https://perma.cc/PU8PV4VJ]. In October 2008, the FSF updated its April 2008 report on how supervisors had 
with the goal of extending "regulation and oversight to all systemically important financial institutions, instruments and markets" 145 and emphasized the use and development of colleges of supervisors in supervising global banks. Furthermore, the Financial Stability Board would expand its membership to include all G20 countries, FSF members, 140 Spain, and the European Commission, ${ }^{147}$ further recognizing the global nature of the financial system.

The G20 leaders generally charged the Financial Stability Board with assessing "vulnerabilities in the financial system," and then identifying and overseeing actions to address them. ${ }^{148}$ Related to colleges of supervisors, the FSB was tasked to "promote coordination and information exchange among authorities responsible for financial stability" and to "set guidelines for, and support the establishment, functioning of, and participation in supervisory colleges, including through the ongoing identification of the most systemically important cross-border firms." 149 In fact, twenty-eight colleges for systemically important institutions were in place by April 2009.150

implemented its extensive recommendations. The FSF noted that authorities had expanded their use of colleges of supervisors to enhance communication among supervisors, "building on existing examples of colleges, such as in the Basel II framework and in the EU." Id. Because of the FSF's earlier work on international financial supervision, the G20 expanded the FSF's role and created the Financial Stability Board with added responsibilities. Financial Stability Forum, Report of the Financial Stability Forum on Enhancing Market and Institutional Resilience 24 (Oct. 10, 2008), http://www.financialstabilityboard.org/press/pr_081009f.pdf [https://perma.cc/R75HJEJU]. The Financial Stability Forum is an organization of financial regulators housed at the Bank for International Settlements in Basel, Switzerland. It periodically meets and issues reports on issues related to financial services regulation on a global basis.

145. The Global Plan for Recovery and Reform, supra note 143, at $\mathbb{1} 15$.

146. Finance ministries and central banks from the following nations are members of the Financial Stability Board: Argentina, Australia, Brazil, Canada, China, France, Germany, Hong Kong, India, Indonesia, Italy, Japan, Mexico, the Netherlands, the Republic of Korea, Russia, Saudi Arabia, Singapore, South Africa, Spain, Switzerland, Turkey, the United Kingdom, and the United States. The following international organizations are also members: the Bank for International Settlements, the European Central Bank, the European Commission, The International Monetary Fund, the Organization for Economic Cooperation and Development and the World Bank, the Basel Committee on Banking Supervision, the Committee on Payment and Settlement Systems, the International Association of Insurance Supervisors, the International Accounting Standards Board, and the International Organization of Securities Commissions. See Member Institutions, FIN. STABLITY BD., http://www.financialstabilityboard. org/members/links.htm [https://perma.cc/QDQ7-AFB3] (last visited Oct. 15, 2020).

147. The Global Plan for Recovery and Reform, supra note 143, at 705.

148. G20, Declaration on Strengthening the Financial System: London Summit, Fin. STABחITY Bd., 1 (Apr. 2, 2009), https://www.fsb.org/wp-content/uploads/london_summit_declaration_ on_str_financial_system.pdf [https://perma.cc/YKA6-Z499].

149. Id. at 1.

150. Progress Report on the Actions of the Washington Action Plan, Servicio de. Difusión de lA Creación Intelectual: Untversidad Nacional de la Plata 1-21, at 15 (Apr. 2, 2009), http://sedici.unlp.edu.ar/bitstream/handle/10915/48031/G20_-_Progress_Report_on_the_Ac tions_of_the_Washington_Action_Plan__21_p._.pdf? sequence=10\&isAllowed=\& https:// perma.cc/6B7F-S33E]. 
Meeting again in September 2009 in Pittsburgh, the G20 leaders assessed progress on their previously agreed goals and noted an improvement in the world economy since they met in London. ${ }^{51}$ They expressed their resolve to ensure the "regulatory system for banks and other financial firms reins in the excesses that led to the crisis" and "[w]here reckless behavior and a lack of responsibility led to crisis, we [the G20] will not allow a return to banking as usual." 152 The G20 declared themselves to be "the premier forum for our international economic cooperation," 153 replacing the G-7 in that role. The G20 noted the substantial progress achieved in establishing supervisory colleges and reinforcing international cooperation among supervisors. ${ }^{154}$ Furthermore, the G20 recognized that solving cross-border insolvency of systemically important financial institutions must occur ${ }^{155}$ so that governments will be less likely to bail out institutions in order to prevent a collapse of the financial system.

In November 2009, the G20 finance ministers met in St. Andrews to review progress thus far.156 They called for the Basel Committee for Banking Supervision to issue stronger prudential standards for banks by the end of 2010.157 They reported that more than thirty colleges have been established for complex financial institutions ${ }^{158}$ and requested the Basel Committee, the FSB, and the International Association of Insurance Supervisors to review the operations of colleges in 2009.159

The Basel Committee on Banking Supervision 160 followed through on the G20 call to review operations of supervisory colleges and urged better supervisory coordination through supervisory colleges globally. In its October 2010 pronouncement, Good Practice Principles on Supervisory Colleges (the Principles), the Basel Committee issued eight general principles on the

151. Leaders' Statement: The Pittsburgb Summit, 1 (Sept. 24-25, 2009), https://g20.org/en/g20/ Documents/2009-Pittsburgh_Declaration.pdf [https://perma.cc/6LA2-8QTT].

152. Id. at 2 .

153. Id. at 3.

154. Id. at 7.

155. Id. at 9.

156. See G20, Communiqué: Meeting of Finance Ministers \& Central Bank Governors, United Kingdom, U.S. DeP'T TREASURY (Nov. 7, 2009), https://www.treasury.gov/press-center/pressreleases/Documents/

g20\%20st \%20andrews\%20\%20draft\%20communique \%20071109\%20\%2015001.pdf [https:// perma.cc/UFS4-3FND].

157. Id. at 2.

158. U.K. Chair of G20, Progress Report on the Economic of Financial Actions of the London, Washington and Pittsburgh G20 Summits, G20, 1-37, at 18 (Nov. 7, 2009), http:// www.g20.utoronto.ca/2009/2009progressreport1 107.pdf [https://perma.cc/E5KN-V83C].

159. Id. at 2.

160. The Basel Committee or BCBS is the primary global standard setter for the prudential regulation of banks. Its forty-five members comprise central banks and bank supervisors from twenty-eight jurisdictions. The Basel Committee- Overview, Bank fOR INT'L SeTtLementr, https://www.bis.org/bcbs/\#: :text=the\%20Basel\%20Committee\%20on\%20Banking,bank\%20 supervisors\%20from\%2028\%20jurisdictions [https://perma.cc/V3M7-MZYR] (last visited Oct. 17, 2020). 
operation of colleges of supervisors for global banks. ${ }^{161}$ The Basel Committee stated that supervisory colleges are not a substitute for effective national supervision of financial institutions. ${ }^{162}$ Furthermore, supervisory colleges are not decision-making bodies, but rather they "provide a framework to enhance effective supervision of international banking groups." 163 The Basel Committee noted that supervisory colleges provide a useful forum in which to share information regarding the overall risk assessment of a banking group and in which to discuss and plan the supervisory assessment of a financial group. ${ }^{164}$ Ultimately, the regular interaction and exchange of information among supervisors within a college should enhance the mutual trust and understanding among the supervisors.

The Principles did not prescribe a particular structure of a supervisory college; rather, the college structure should be flexible and proportionate to the size and complexity of the financial institution. The Principles did recognize that the home supervisor who leads the college could designate members of a core college and a general college.165 The home supervisor should have regular, continuous communication with members of the core college who represent the jurisdictions in which significant operations of the financial institution exist. Members of the general college represent jurisdictions where the financial institution has less significant operations. The college should hold regular physical meetings among the supervisors and the core college should meet at least once annually.

In June 2014, the Basel Committee on Banking Supervision issued its Principles for Effective Supervisory Colleges replacing its earlier October 2010 pronouncement. ${ }^{166}$ After several years of experience with an increased number of supervisory colleges for global banking groups, the Basel Committee intended to further improve the operation of supervisory colleges and ultimately improve the stability of the global financial system. The Basel Committee noted: "[c]olleges are now an important component of effective supervisory oversight of an international banking group and the G20 has reinforced the significance of colleges in the wake of the financial crisis."167

The 2014 Principles emphasize the importance of ongoing information sharing and not just sharing information at supervisory college meetings. ${ }^{168}$ Information sharing is only effective when there is mutual trust resulting

161. See Basel Comm. on Banking Supervision, Good Practice Principles on Supervisory Colleges, BANK FOR INT'L SETTLEMENTS, 1-29 (Oct. 2010), https://www.bis.org/publ/bcbs177.pdf [https://perma.cc/M2BB-M7H8].

162. Id. at 1.

163. Id.

164. Id. at 2.

165. See id. at 3-4.

166. See Basel Comm. on Banking Supervision, Principles for Effective Supervisory Colleges, BANK FOR INT'L SETTLEMENJT, 1-30 (June 26, 2014), https://www.bis.org/publ/bcbs287.pdf [https:/ /perma.cc/3PGQ-EQ3M].

167. Id. at 1 .

168. Id. at 2. 
from confidence in the information flow between and among supervisors. The 2014 Principles also recognized the importance of more involvement by host supervisors but recognized that there is a balance between the number of members of the college and the effectiveness of the college. ${ }^{169}$

Learning from its additional experience with supervisory colleges, the Basel Committee includes more advice on the structure of colleges but does not specify a structure for supervisory colleges. A supervisory college is organized based on the structure and geographic scope of the global bank to which it relates. The home supervisor is responsible for structuring the supervisory college. 170 Supervisors in countries where the global bank operates (the host supervisors) necessarily have an interest in the overall stability of the global bank. ${ }^{171}$

In addition to creating the structure of the supervisory college, the home supervisor has the important role of designing and coordinating the work of the supervisory college. ${ }^{172}$ The home supervisor sets the agenda for the supervisory college meetings, ensures that relevant supervisory information is shared as appropriate among the members of the college, and provides the mechanism for such sharing and communication generally within the college (such as a secure web platform for communication and sharing documents, many of which are confidential). ${ }^{173}$ To assist in this information sharing, the Basel Committee recommends entering into memoranda of understanding that provide for the sharing of confidential information. ${ }^{174}$ Members of a supervisory college should also collaborate in their work, such as conducting joint on-site inspections of a global bank or reaching a joint risk assessment of the global bank. ${ }^{175}$ Once the supervisors within a college reach a joint risk assessment, they should coordinate on the timing and content of subsequent communication to the global bank of the assessment. ${ }^{176}$

The 2014 Principles extensively discuss crisis management groups and the operation of supervisory colleges. With the issuance by the Financial Stability Board of its 2011 Key Attributes of Effective Resolution Regimes for Financial Institutions, 177 more attention has been focused on crisis

169. Id. at 5 .

170. Id.

171. Id.

172. Id. See also Basel Comm. on Banking Supervision, Principles for Effective Supervisory Colleges, supra note 166 , at 7 .

173. Id. at 8.

174. See id. at 9.

175. Id. at 12.

176. Id. at 15 .

177. Key Attributes of Effective Resolution Regimes for Financial Institutions, FIN. STABחITY BD., (Oct. 2011), http://www.fsb.org/wp-content/uploads/r_111104cc.pdf?page_moved=1 [https:// perma.cc/RRQ8-JVAN] [hereinafter Effective Resolution Regimes for Financial Institutions (2011)]. The FSB later updated this report in October of 2014. See Key Attributes of Effective Resolution Regimes for Financial Institutions, FIN. STABlLtTY BD., (Oct. 2014), http://www.fsb.org/wpcontent/uploads/r_141015.pdf [https://perma.cc/]R6N-GLQD] [hereinafter Effective Resolution Regimes for Financial Institutions (2014)]. 
preparedness and the operation of crisis management groups. Crisis management groups address the recovery planning and resolution of global banks and include resolution authorities and ministries of finance as well as supervisory authorities among their membership. ${ }^{178}$ The supervisory college focuses on information-sharing among supervisors when the global bank is a going concern. ${ }^{179}$ The crisis management groups come into play when the global bank has reached "a point of non-viability." 180 When this shift of responsibility actually occurs is not clear or definite. Thus, a weakness in the supervision of global banks is this uncertainty regarding when the resolution authorities step in and the supervisors relinquish their supervisory role.

Thus far, this article focused on prudential supervisory standards of the Basel Committee and the Financial Services Board. EU Member States strongly influenced the development of these standards.181 Member States were involved in the resolution of the Herstatt Bank, Banco Ambrosiano, BCCI, and other banks during the Great Recession. European Union concern with supervisory cooperation has been long-standing and its supranational legal order has allowed for the deepened development of supervisory cooperation and ultimately the creation of a supranational financial supervisory agency-the Single Supervisory Mechanism of the European Central Bank.

\section{European Union and Supervisory Colleges}

A concern among EU officials in the late 1990s and early 2000 s was to reform the EU legislative process to accelerate the passage of necessary legislation in order to further integrate the EU financial services market. ${ }^{182}$ The Council of Ministers appointed Baron Alexandre Lamfalussy, a wellrespected central banker, former president of the European Monetary Institute (predecessor to the European Central Bank), and past director of the Bank for International Settlements, to chair a committee to examine and make recommendations regarding the EU legislative process with respect to financial services regulation. ${ }^{183}$ The Council urged the committee to focus on the "practical arrangements for implementation of the Community rules" of the legislative process. ${ }^{184}$

178. Effective Resolution Regimes for Financial Institutions (2011), supra note 177, at 16.

179. Id.

180. Id. at 7 .

181. Newman \& Posner, supra note 3, at 77.

182. Alexandre Lamfalussy et al., Final Report of the Committee of Wise Men on The Regulation of European Securities Markets, COMm. WISE MEN, 98 (Feb. 15, 2001), https:// www.esma.europa.eu/sites/default/files/library/2015/11/lamfalussy_report.pdf [https:// perma.cc/76BT-6S23].

183. European Commission Press Release Conseil/00/263, 2283rd Council MeetingECOFIN-Brussels, (July 17, 2000).

184. Id. at 12. The Council specifically prohibited the Committee of Wise Men from making recommendations on securities industry supervision. See id. at 13. 
In its Final Report, the Committee identified the legislative process as the central impediment to integrating financial markets by 2005.185 The report noted that the necessary EU-wide regulations of the securities markets were not present, and that this absence has hindered the growth of the EU capital markets. ${ }^{186}$ The legislative process in the European Union was too timeconsuming and could not keep up with changes and developments in the fast-moving, global capital markets. ${ }^{187}$ The co-decision procedure for enacting laws (the typical procedure used to pass EU internal market legislation) ${ }^{188}$ generally spanned a minimum of two years, and the procedure was even more sluggish in enacting laws pertaining to financial services. ${ }^{189}$ Within the European Union, there were over forty public bodies (in the then fifteen Member States) that were responsible for regulating the securities industry. 190 Consequently, once the European Union enacted a directive, the implementation of securities laws within the Member States was frequently inconsistent.

The Committee, after considerable consultation with interested participants, recommended a four-level approach to lawmaking related to financial services in the European Union. ${ }^{191}$ Level 1 of the Lamfalussy procedure refers to the adoption of directives and regulations using the codecision procedure at the EU level. ${ }^{192}$ Level 2 is the implementation of the law by "filling in the details." 193 The Report of the Wise Men recommended the creation of a special committee of national supervisory officials to draft these details. ${ }^{194}$ Level 3 refers to greater cooperation among national supervisors to "ensure consistent implementation and enforcement."195 Similar to Level 2, the Lamfalussy Report recommended for Level 3 the

185. Alexandre Lamfalussy et al, supra note 182, at 5, 26.

186. $I d$. at 11 .

187. Id. at 13 (noting that the Committee suggested that politicians set reachable short-term goals for integration and make a concerted effort to reach those goals).

188. A detailed description of the co-decision procedure used to enact EU legislation is beyond the scope of this article. Generally, co-decision requires agreement between the Council of the European Union and the European Parliament before legislation becomes law. See generally About Parliament: Legislative Powers, Eur. Parlinment, https://www.europarl.europa.eu/aboutparliament/en/powers-and-procedures/legislative-powers [https://perma.cc/7VBN-5JKC] (last visited Oct. 15, 2020).

189. Alexandre Lamfalussy et al., supra note 182, at 14; Kees Van Dijkhuizen, A Functional Approach to Fifty Years of Banking Supervision, in Banking Supervision AT THE Crossroads 44, 44, (Thea Kuppens et al. eds., 2003).

190. Alexandre Lamfalussy et al., supra note 182 , at 15 .

191. Id. at 19.

192. Id. at 22. A directive is a type of EU legislation that sets out the objectives of the law but requires member states to enact national legislation to implement the law. See Klaus-Dieter Borchardt, The ABC of Community Law, EUR. CMTYS., 63-71 (Dec. 2016), https://op.europa.eu/ en/publication-detail/-/publication/5d4f8cde-de25-11e7-a506-01aa75ed71a1 [https://perma.cc/ 9TJ9-M6GM].

193. Alexandre Lamfalussy et al., supra note 182 , at 28.

194. Id.

195. Id. at 37. 
creation of a committee to coordinate supervisory practice among EU member states. ${ }^{196}$ Level 4 refers to more effective enforcement of EU laws. ${ }^{197}$ The European Council at its March 2001 Stockholm meeting endorsed the Final Report of the Lamfalussy Committee. ${ }^{198}$

Resulting from the Lamfalussy Report and the EU Council Resolutions, the Committee of European Banking Supervisors (CEBS) was created. CEBS consisted of the bank supervisory authorities of the European Union Member States and had the objective "to foster supervisory convergence across the Community." 199 In furtherance of this objective, CEBS was also active in supporting the development of colleges of supervisors of crossborder banks within the European Union. In December 2007, CEBS issued two documents, one entitled Range of Practices on Supervisory Colleges and Home-Host Cooperation ${ }^{200}$ and the other, Template for a Multilateral Cooperation Coordination Agreement on the Supervision of XY Group,201 which provided non-binding guidelines on the operation of colleges of supervisors.

As stated earlier, the Great Recession had focused renewed attention on colleges of supervisors as one of several tools to reduce risk within the international financial system and the G20 had called on the Financial Services Board and the Basel Committee to improve further supervisory cooperation.202 CEBS updated both documents in January 2009203 and provided more specific detail on the operation of the college of supervisors.

196. Id. at $37-39$.

197. Id. at 40.

198. Presidency Conclusions, Resolution of the European Council on More Effective Securities Market Regulation in the European Union, Stockholm European Council (Mar. 23, 2001) (recommending that the priorities set forth by the Wise Men be implemented).

199. Commission Decision of January 23, 2009 Establishing the Committee of Eur. Bank Supervisors, 2009 O.J. (L 25) 24, II 13 (EC).

200. Range of Practices on Supervisory Colleges and Home-Host Cooperation, Comm. Eur. BANkING SUPERviSORS (Dec. 27, 2007), https://eba.europa.eu/sites/default/documents/files/documents/ 10180/16166/01743c25-503e-4be7-bf13-56cabbdecb2d/

CEBS\%202007\%2075\%20\%28Range\%20of\%20practices\%29\%20final.pdf [https://perma.cc/ H4GV-GK4G].

201. Template for a Multilateral Cooperation and Coordination Agreement on the Supervision of XY Group, Comm. Eur. BANKING Supervisors (Jan. 27, 2009), https://eba.europa.eu/sites/default/ documents/files/documents/10180/16166/f4bf7b39-260c-4391-9d53-cc27a4fd2aa9/

Template_Jan09.pdf [https://perma.cc/H7TG-26]A] (noting that the template document was a form agreement, to be signed among supervisors, regarding the organization of the colleges and setting forth how the supervisors will interact with one another in supervising a particular bank). The agreement goes into detail about the exchange of information and communication within the group and sets forth responsibilities of each of the regulators who are a party to the agreement. Id.

202. G20 Leaders, supra note 139.

203. Press Release, Franca Rosa Congiu, Eur. Banking Authority, CEBS Has Published a Revised Template for Written Agreements Between Supervisors for the Functioning of Colleges, Jan. 27, 2009), https://eba.europa.eu/cebs-has-published-a-revised-template-forwritten-agreements-between-supervisors-for-the-functioning-of-colleges- $[\mathrm{https} / /$ perma.cc $4 \mathrm{X} 2 \mathrm{P}-\mathrm{G} 29 \mathrm{H}$ ] (CEIOPS and the Interim Working Group on Financial Conglomerates joined in issuing these documents). 
In its Colleges of Supervisors - 10 Common Principles, ${ }^{204}$ CEBS provides that a college of supervisors shall supervise any cross-border insurance group, banking group or financial conglomerate. ${ }^{205}$ The colleges "flexible, permanent fora for cooperation and coordination among financial supervisory authorities" 206 "shall have agreements in place describing the cooperation between the supervisors and the practical organization of the supervisory activities" of the financial institution. ${ }^{207}$ For banking groups, the consolidating supervisor as defined in the Capital Requirements Directive "shall initiate the cooperation process." 208 The colleges shall also promote harmonization of supervisory approaches and coordinate all major supervisory decisions. ${ }^{209}$ In addition, the colleges shall plan and coordinate supervisory on-site inspections and share the findings from such visits with other members of the college. 210

While not significantly different from the 2007 version, the 2009 Template for a Multilateral Cooperation Coordination Agreement removes some discretion given to the supervisor under the earlier agreement and requires supervisors to cooperate more fully with their peers in the supervision of cross-border banks. ${ }^{211}$ For instance, the new agreement adds a provision stating, "[s]hould the authorities in a College not reach an agreement, as foreseen by the CRD [Capital Requirements Directive] the matter may be referred for mediation to the Committee of European Banking Supervisors."212

In January 2009, the European Commission in a decision further strengthened CEBS's supervisory cooperation role ${ }^{213}$ by providing that the committee shall "mediate or facilitate mediation between supervisory authorities in cases specified in the relevant legislation or at the request of the supervisory authority." 214 Under this provision, CEBS is authorized to mediate between supervisors-authority it did not have under the 2004 decision originally creating CEBS. ${ }^{215}$ Previously, colleges of supervisors

204. Comm. Eur. Banking Supervisors [CEBS], Comm. Eur. Insurance \& Occupational Pensions Supervisors [CEIOPS], Colleges of Supervisors-10 Common Principles, at 1-5, CEIOPS-SEC-54/08, CEBS 2008124 (Jan. 27, 2009), https://www.eiopa.europa.ew/sites/ default/files/publications/stand_guide_recom/cebs-ceiops-iwcfc-10-principles-colleges-ofsupervisors.pdf? source=search [https://perma.cc/VH9N-NBTJ].

205. Id. at 1-2.

206. Id. at 2.

207. Id. at 3.

208. Id. at 3-4.

209. Id. at 4.

210. Id. at 4-5.

211. See Template for a Multilateral Cooperation and Coordination Agreement on the Supervision of $X Y$ Group, supra note 201.

212. Id. at $\$ 6.1(26)$.

213. Commission Decision of Jan. 23, 2009 Establishing the Committee of European Bank Supervisors, supra note 169, art. 16, at 27 (repealing the 2004 decision initially establishing the Committee of European Banks Supervisors).

214. Id. at art. 4(1)(a), 25.

215. See Commission Decision of November 5, 2003, Establishing the Committee of Eur. Bank Supervisors, 2004 OJ. (L 3) 28 (EC). 
made all decisions by consensus and had no mechanism to resolve conflicts other than by negotiation and mutual cooperation.216 At least for supervisory authorities within the European Union, this 2009 decision allows the CEBS to mediate these disputes.217 This decision also specifically requires CEBS to "contribute to insuring the efficient and consistent functioning of colleges of supervisors in particular through setting guidelines for the operational functioning of colleges, monitoring the coherence of the practices of different colleges and sharing those practices."118 CEBS is authorized to ensure that colleges of supervisors apply EU law and implementing measures consistently across financial institutions and that cross-border banks are supervised consistently by colleges of supervisors with varying membership. ${ }^{219}$

The EU took additional steps to buttress colleges as a supervisory tool. 220 In several EU directives, the European Union institutionalized greater cooperation among supervisors supervising cross-border banks.221 In the adoption of the Basel II directive dealing with capital requirements of credit institutions, ${ }^{222}$ the European Union specifically created rules dealing with cooperation among supervisors of cross-border banks operating in the European Union. In its proposal for the Basel II Directive,223 the European Commission noted that the establishment of colleges of supervisors would "facilitate the tasks of the consolidating supervisor and the host supervisors." 224 Chapter 4 (Articles 124 through 144) of this directive lays

\section{Id.}

217. Commission Decision of January 23, 2009 Establishing the Committee of Eur. Bank Supervisors, 2009 O.J. (L 25) 25, art. 4(1)(a), (EC).

218. Id.

219. On December 17, 2009, CEBS issued a consultation paper on guidelines for the operational functioning of colleges of supervisors. See Consultation Paper on CEBS's Guidelines for the Operational Functioning of Colleges, Comm. Eur. Banking Supervisors, 19 (Dec. 17, 2009), https://eba.europa.eu/sites/default/documents/files/documents/10180/37070/1a3c55a174c0-40de-b17f-993aa3d39b86/CP34.pdf?retry=1 [https://perma.cc/6KQA-2VMB].

220. See, e.g., Council Directive 2006/48 of the European Parliament and of the Council of 14 June 2006 Relating to the Taking $\mathrm{U}_{\mathrm{p}}$ and Pursuit of the Business of Credit Institutions (Recast), 2006 O.J. (L 177) 1 (EC).

221. See id.; Council Directive 2006/49 of the European Parliament and of the Council of 14 June 2006 on the Capital Adequacy of Investment Firms and Credit Institutions (Recast), 2006 O.J. (L 177) 201 (EC).

222. Council Directive 2006/48 of the European Parliament and of the Council of 14 June 2006 Relating to the Taking Up and Pursuit of the Business of Credit Institutions (Recast), 2006 O.J. (L 177) 1 (EC); Council Directive 2006/49 of the European Parliament and of the Council of 14 June 2006 on the Capital Adequacy of Investment Firms and Credit Institutions (Recast), 2006 O.J. (L 177) 201 (EC).

223. Proposal for a Directive of the Eur. Parliament and of the Council Amending Directives 2006/48/EC and 2006/49/EC as Regards Banks Affiliated to Central Institutions, Certain Own Funds Items, Large Exposures, Supervisory Arrangements, and Crisis Management, at 2, COM (2008) 602 final Jan. 10, 2008).

224. Id. at 9. 
out rules determining which supervisor, also known as the lead supervisor, exercises consolidated supervision over the cross-border bank. 225

One weakness of the college of supervisors under these previous directives was the lack of a mandatory mediation process if the supervisors cannot agree on an action with respect to the supervision of the financial institution. ${ }^{226}$ As seen during the Great Recession, this lack of mediation allowed supervisors to act on their own and not in coordination with their peers. For example, in the fall 2008 rescue of Fortis, the financial group with operations in Belgium, the Netherlands, and Luxembourg, the national supervisors struggled to coordinate their actions.227 At first, the Benelux governments bought 49 percent of the equity of Fortis.228 Then a few days later, the Dutch government seized the Dutch operations of Fortis and the Belgian and Luxembourgian operations were sold to BNP Paribas.229 These events illustrate reveal a lack of effective supervisory cooperation, particularly during times of crisis. Recognizing the weaknesses in the supervisory system highlighted by the financial crises, the European Union responded with legislative proposals to reform the system within the European Union. ${ }^{230}$

\section{European Union's Reform of Financial Supervision}

As a response to the Great Recession and multiple bank failures, EU leaders revisited the supervisory structure of the EU banking system. On February 25, 2009, a high level group of advisors, chaired by Jacques de Larosière, former Governor of the Banque de France, issued its report on the reform of the European Union system of financial supervision, also known as the Larosière Report.231 Appointed by Jose Barroso, the President of the European Commission, in the fall of 2008, the High-Level Group was charged with a broad mandate "to make proposals to strengthen European supervisory arrangements covering all financial sectors, with the objective to

225. Council Directive 2006/48 of the European Parliament and of the Council of 14 June 2006 Relating to the Taking Up and Pursuit of the Business of Credit Institutions (Recast), 2006 O.J. (L 177) art. 124-44, 1 (EC).

226. See id.; Council Directive 2006/49 of the European Parliament and of the Council of 14 June 2006 on the Capital Adequacy of Investment Firms and Credit Institutions (Recast), 2006 O.J. (L 177) 201 (EC).

227. Nikki Tait \& Jennifer Hughes, Trichet Says Regulation Must Be Extended, Fin. Times, (Feb. 23, 2009), https://www.ft.com/content/3eb481e0-01a6-11de-8199-000077b07658 [https:// perma.cc/M8YZ-PCMM].

228. Ulrich Volz, Europe Needs a United Approach to the Credit Crunch, WaLl ST. J., (Oct. 7, 2008, 12:01 AM), https://www.wsj.com/articles/SB122333891159809861 [https://perma.cc/ B7YL-5E7M].

229. Id.

230. See Jacques de Larosière et al., The High-Level Group on Financial Supervision in the EU Report of Brussels, (Feb. 25, 2009), https://www.eiopa.europa.eu/sites/default/files/publications/ pdfs/publication14527_en.pdf [https://perma.cc/Q5K2-3PQL].

231. Id. (holding eleven public meetings and consulting widely to develop its thirty-one recommendations to improve financial services regulation within the EU). 
establish a more efficient, integrated and sustainable European system of supervision."232 While a complete analysis of this report is beyond the scope of this article, this article will focus on the report's recommendations related to supervisory cooperation within the European Union. The Larosière Report recommended that, for cross-border institutions, the colleges of supervisors introduced by the revised Capital Requirements Directive and the then proposed Solvency II Directive should take the lead in supervision. ${ }^{233}$ The colleges of supervisors should be strengthened by "participation of representatives of the secretariat of the Level 3 committees as well as of the European Central Bank and European System of Central Bank Supervisors."234 The Larosière Report in Recommendation 18 advised that "colleges of supervisors would be set up for all major cross-border institutions." 235

The report also states that the "relatively restricted use of supervisory colleges should be expanded immediately."236 By the end of 2009, supervisory colleges should be established for all major cross-border firms within the European Union, 237 estimated to be at least fifty financial institutions. ${ }^{238}$ The Level 3 committees ${ }^{239}$ would participate in this process by defining the final supervisory practices and arrangements for the functioning of the colleges of supervisors. ${ }^{240}$ "The clear intent is to expand the mandate of CEBS - to be more inclusive of the supervisory players and to broaden the tasks of colleges beyond those stated in the CRD."241 This

232. European Commission Press Release IP/08/1679, High Level Expert Group on EU Financial Supervision to Hold First Meeting of 12 November (Nov. 11, 2008).

233. Larosière et al., supra note 230, at 47 (enacting the Solvency Directive later); See also Directive 2009/138, 2006 O.J. (L 335) 1 (EC).

234. Id. The Level 3 committees refer to the Committee of European Banking Supervisors (CEBS), the Committee of European Securities Regulators (CESR), and the Committee of European Insurance and Occupational Pension Supervisors (CEIOPS). These committees were set up under the Lamfalussy process to advise the Commission and its committees on implementing measures need to effectuate financial regulation. See generally Duncan Alford, The Lamfalussy Process and EU Bank Regulation: Another Step on The Road to Pan-European Regulation, 25 ANN. Rev. BANking \& Fin. L. 389, 397-406 (2006).

235. Larosière et al., supra note 230 , at 48.

236. Id. at 51 .

237. Id.

238. Id. Larosière et al., supra note 230 , at $51, \mathrm{n} .13$; see infra Annex $\Pi$ (listing systemically important financial institutions that the Financial Stability Board purportedly compiled in November 2009).

239. See generally Alford, The Lamfalussy Process and EU Bank Regulation, supra note 234.

240. The Larosière Report envisioned that the Level 3 committees under the Lamfalussy process would eventually become European authorities or regulatory agencies - the European Banking Authority, the European Insurance Authority, and the European Securities Authority. Larosière et al., supra note 230, at 52-53. See also Duncan E. Alford, The Operation of Supervisory Colleges after the Single Supervisory Mechanism of the European Banking Union, BaNkING L.J. $\$ 2019-2.02$, at 2-5 (discussing the best practice documents issued by CEBS on the operation of colleges of supervisors).

241. Duncan Alford, Supervisory Colleges: The Global Financial Crisis and Improving International Supervisory Coordination, 24 EMORY IN'J'L L. REv. 57, 67 (2010). 
recommendation is a logical precursor to the report's medium-term goal of creating a European System of Financial Supervision (ESFS). ${ }^{242}$ The ESFS would transform the Level 3 committees into three supervisory authorities, one for each financial sector: banking, securities, and insurance. ${ }^{243}$ The authorities are tasked to ensure "consistency of prudential supervision"244 and to define "common supervisory practices and arrangements for the functioning of the colleges of supervisors."245

The European Council of the European Union took up the Larosière Report at its March 2009 meeting. ${ }^{446}$ The Council "agreed on the need to improve the regulation and supervision of financial institutions in the [European Union] and that the report from the High Level Group on financial supervision chaired by Jacques de Larosière is the basis for action." 247

In May 2009, the European Commission issued a communication describing its planned actions based on the Larosière report, 248 calling for comments from interested parties during a consultation period, and setting forth a revision of the European supervisory structure based on two pillars: (1) the creation of a European Systemic Risk Council (ESRC) to deal with macroprudential supervision and (2) the creation of the European System of Financial Supervisors (ESFS) to deal with micro-prudential supervision, that is, supervision of individual financial institutions. ${ }^{249}$ The ESFS is charged with developing a "harmonized core set of standards" 250 and a "common supervisory culture." 251 The Commission's legislative proposals go beyond the framework developed at the G20 summits and create an integrated financial supervisory structure within the European Union. ${ }^{252}$

The Commission stated that the current Level 3 Committees must move beyond being advisory bodies and should become European supervisory authorities with legal personalities and additional powers and responsibilities. ${ }^{253}$ As part of the ESFS, the Commission proposed creating

242. Larosière et al., supra note 230 , at 52-55.

243. Id. at 52 .

244. Id. at 53 .

245. Id.

246. The European Council, consisting of the Heads of State of the Member States of the European Union, meets quarterly. See European Council Overview, EUROPA, https://europa.eu/ european-union/about-eu/institutions-bodies/european-council_en [https://perma.cc/245PYRDC] (last visited Oct. 15, 2020).

247. Presidency Conclusions, Brussels European Council, 78780/90, at 3 (Mar. 20, 2009), http://data.consilium.europa.eu/doc/document/ST-7880-2009-INTT/en/pdf [https://perma.cc/ V6ND-6SHG].

248. Communication from the Commission: European Financial Supervision, at 2, COM (2009) 252 final (May 27, 2009).

249. Id. at 3.

250. Id. at 4.

251. Id.

252. Id. at 8 .

253. Id. at 8-9. 
three new supervisory authorities-the European Banking Authority (the EBA), the European Securities Markets Authority (the ESMA), and the European Insurance and Occupational Pensions Authority (the EIOPA).254

The May communication relies heavily on colleges of supervisors as "the lynchpin of the supervisory system" 255 as they will ensure "a balanced flow of information between home and host authorities."256 The EBA will participate in the colleges as an observer, will ensure that colleges use consistent practices in supervising financial instructions, ${ }^{257}$ and will facilitate the distribution of micro-prudential information to all national supervisors in a particular college. ${ }^{258}$ The expectation is that the college will take an institution-wide view regarding prudential supervision, rather than just a national view. 259

After negotiations within the Council of Ministers and between the Council of Ministers and the European Parliament, the final EBA regulation was enacted and did strengthen the financial supervisory system in the European Union. The EBA can issue binding technical standards, subject to review by the European Commission. 260 But according to the regulation, the standards shall not include public "policy choices,"261 an ambiguous phrase that limits EBA discretion. The EBA Board of Supervisors must approve any standards by qualified majority voting.262 The regulation continues the EBA's role in a college of supervisors ${ }^{263}$ and encourages the development of a common reporting format of prudential information. ${ }^{264}$ The EBA is an observer in all colleges of supervisors and is obligated to create a central system for the collection of prudential information on financial institutions. ${ }^{265}$ The EBA can settle disputes among supervisors. ${ }^{260}$ To ensure its independence, the EBA has a separate budget, financed by the EU General Budget and Member States. ${ }^{267}$

254. Id.

255. Id. at 9 .

256. Id.

257. European Commission MEMO/09/251, The Commission, Financial Supervision Frequently Asked Questions (May 27, 2009).

258. Id.

259. Id. at 3 .

260. Commission Regulation 1093/10 of Dec. 15, 2010, Establishing a European Supervisory Authority (European Banking Authority), 2010 O.J. (L 331) 12, 23.

261. Id. at art. 10(1).

262. Id. at art. 44(1). Qualified majority voting is the method of voting used for approval of most EU legislation by the Council of Ministers. See generally Qualified Majority, CounCuL EUR. UNION, https://www.consilium.europa.eu/en/council-eu/voting-system/qualified-major ity/ (last visited Sept. 3, 2020), [https://perma.cc/74QK-JDHP].

263. Commission Regulation 1093/10, art. 8(1)(b), at 212010 O.J. (L 331) 12, 23.

264. Id. at art. 29.

265. Id. at art. 12 .

266. Id. at art. $19(1)$.

267. Id. at art. 62(1)(a-c). 


\section{Single Supervisory Mechanism of the European Union}

The sovereign debt crisis in certain EU Member States beginning in 2010 highlighted the continuing weaknesses in the supervisory regime under the EBA. National supervisors continued to play a significant role in the supervision of cross-border banking groups. ${ }^{268}$ The connection between sovereign bonds and banks severely weakened confidence in the banking system in some EU Member States.269 As a result, the European Commission proposed the Banking Union in order to sever the link between sovereign debt and the banking system and to improve the supervision of cross-border banks.270 The Banking Union proposal consisted of three pillars: the Single Supervisory Mechanism, the Single Resolution Mechanism, and a common deposit insurance scheme.271

The European Union brought into effect the first pillar of the Banking Union-the Single Supervisory Mechanism (SSM)-on November 4, 2014.272 At that time, the European Central Bank (ECB) became the prudential supervisor of the 120 largest banking groups (or significant financial institutions) in the Eurozone. ${ }^{273}$ These 120 banking groups represented approximately 85 percent of the banking assets within the Eurozone. 274

The legal basis for the ECB's role as the single European prudential supervisor is Article 127(6) of the Treaty on the Functioning of the European Union. ${ }^{275}$ The appointment of another EU institution or agency would have required a treaty amendment which was not politically feasible at the time. ${ }^{276}$ Nineteen Member States of the European Union are currently members of the Eurozone and thus also the SSM.277 Bulgaria, Croatia, the

268. Special Report - European Banking Supervision Taking Shape - EBA and its Changing Context, Eur. CT. AudiTors, 1, 8 (2014), https://eur-lex.europa.eu/legal-content/EN/TXT/PDF/ ?uric LEX:52014SA0005 \& rid=3 [https://perma.cc/5ADC-TLLX].

269. See José Manuel González-Páramo, Member Exec. Bd. of the Eur. Cent. Bank, Speech at the XXIV Mondea y Crédito Symposium Madrid (Nov. 4, 2011) in Fosé Manuel GonzálezParamo: The ECB and the Sovereign Debt Crisis, BANK fOR INT'L SeTtLements (Nov. 7, 2011), https://www.bis.org/review/r111107c.pdf [https://perma.cc/5PWU-WJJG].

270. See Communication from the Commission to the European Parliament and the Council $A$ Roadmap Towards a Banking Union, at 3, COM (2012) 510 final (Dec. 12, 2012).

271. Id. at 4,6 .

272. Guide to Banking Supervision, Eur. Central BANK 1-2 (Sept. 2014), https:// www.ecb.europa.eu/pub/pdf/other/ssmguidebankingsupervision201409en.pdf [https:// perma.cc/YA7G-ZDD6].

273. Id. at $9,12$.

274. $I d$. at 12 (The Eurozone refers to the Member States who have adopted the euro as their currency).

275. Consolidated Version of the Treaty on the Functioning of the European Union, art. 127(6), Oct. 26, 2012, 2012 O.J. (C 326) 103.

276. Peterson Inst. for Int'l Econ., Jacob Funk Kirkegaard, How Europe Can Muddle Through its Crisis, at 1, No. PB10-27 (Dec. 2010).

277. See Which Countries Use the Euro, Eur. UNION, https://europa.eu/european-union/abouteu/euro/which-countries-use-euro_en [https://perma.cc/V8ZE-AZAY] (last visited Oct. 15, 2020). 
Czech Republic, Hungary, Poland, and Romania are not members of the Eurozone but, by the terms of their accession treaties with the European Union, they are required to join the Eurozone once they have met certain economic criteria.278 Denmark and the United Kingdom are not obligated to join the Eurozone under the EU treaties. ${ }^{279}$ Sweden is not a member of the Eurozone and in the past has resisted joining the Banking Union because of the necessary loss of authority over its largest banks.280

The second pillar of the EU Banking Union-the Single Resolution Mechanism-began operation in 2016.281 But the SRM will not be fully operational and funded until 2022.282 The third pillar-a common deposit insurance scheme for the Eurozone-is currently being debated within the European Union institutions and it is still a long way from implementation. ${ }^{283}$

Prior to the creation of the SSM, banks throughout the European Union were supervised by national competent authorities (NCAs) or national bank supervisors with some coordination by supervisory colleges and the EBA as described above. ${ }^{284}$ As a result, national supervisors took different supervisory approaches and took advantage of national discretions available in EU banking laws. ${ }^{285}$ Banking groups recognized this regulatory arbitrage and structured their banking operations accordingly. 286

Under the SSM, the ability to take advantage of this regulatory arbitrage is reduced. 287 The ECB supervises the largest banks in the Eurozone; the

278. Act Concerning the Conditions of Accession of the Czech Republic, the Republic of Estonia, the Republic of Cyprus, the Republic of Latvia, the Republic of Lithuania, the Republic of Hungary, the Republic of Malta, the Republic of Poland, the Republic of Slovenia, and the Slovak Republic and the Adjustments to the Treaties on Which the European Union is Founded, 2003 O.J. (L 236) 33.

279. Glossary of Summaries: Opting Out, EuR-LEx, https://eur-lex.europa.eu/summary/glossary/ opting_out.html [https://perma.cc/D8VV-P3A3] (last visited Oct. 15, 2020).

280. Helene Duaschy, Sweden Mulls Membership in European Banking Union, Agence Fr. PrESSE (Nov. 7, 2017), https://www.yahoo.com/news/sweden-mulls-membership-europeanbanking-union-031351638.html [https://perma.cc/XRH4-K2UY].

281. Fact Sbeets on the European Union: Banking Union, Eur. Parliament, https:// www.europarl.europa.eu/factsheets/en/sheet/88/banking-union [https://perma.cc/2S4KUKQB] (last visited Oct. 15, 2020).

282. See Single Resolution Fund, Single Resolutron Board, at 4, 11 (May 2016), https:// srb.europa.eu/sites/srbsite/files/single_resolution_fund_0.pdf [https://perma.cc/6JRW-LJQY].

283. Proposal for a Regulation of the European Parliament and of the Council Amending Regulation (EU) 806/2014 in Order to Establish a European Deposit Insurance Scheme, at 2, COM (2015) 586 final (Nov. 24, 2015); Fact Sheets on the European Union: Banking Union, supra note 281 .

284. See Special Report - European Banking Supervision Taking Shape - EBA and its Changing Context, supra note 268 , at 8 .

285. Eddy Wymeersch, The Single Supervisory Mechanism or "SSM," Part One of the Banking Union 8 (Nat'l Bank of Belg., Working Paper No. 240/2014, 2014), https://papers.ssrn.com/ sol3/papers.cfm?abstract_id=2397800 [https://perma.cc/4TX3-TWS6].

286. Id.

287. Id. 
smaller banks, or more specifically the less significant banking groups, will continue to be supervised by national supervisors under the general oversight of the ECB. ${ }^{288}$ These smaller banks numbering several thousand represent approximately eighteen percent of Eurozone banking assets and the vast majority are located in Austria, Germany, and Italy.289 The result is a two-tiered system of bank supervision, ${ }^{200}$ in some ways, similar to the dual banking system in the United States. ${ }^{291}$ Banking groups with their home office outside the Eurozone will continue to be supervised by the national bank supervisor of their home jurisdiction.292 The SSM does allow EU Member States outside of the Eurozone to opt into the ECB's supervisory regime but, thus far, no EU Member State has done so. 293

Inevitably after November 2014, the SSM caused the reorganization of supervisory colleges both within and without the Eurozone. ${ }^{294}$ The ECB took over the role of national bank supervisors of the nineteen Eurozone nations in the supervisory colleges that previously existed. ${ }^{295}$ If a banking group operates only in the Eurozone, no supervisory college exists because the ECB assumes the role of all the national bank supervisors. ${ }^{296}$ If the head

288. Id. at 13 .

289. Sabine Lautenschläger, Member of the Executive Board of the ECB and Vice-Chair of the ECB's Supervisory Board, Speech at the Banking Evening of the Deutsche Bundesbank Regional Office in Baden-Württemberg (Feb. 22, 2016) in Caught in the Middle? Small and Medium Sized Banks and European Banking Supervision, Eur. CenTral Bank (Feb. 22, 2016), https://www.bankingsupervision.europa.eu/press/speeches/date/2016/html/se160222.en.html [https://perma.cc/XN6W-VEHB].

290. Wymeersch, supra note 285, at 13.

291. Michael P. Malloy, \$1B.10 State Regulators in Banking Law and Regulation (2d. ed. 2020).

292. Ismael Ahmad Fontán et al., Banking Supervision and Resolution in the EU: Effects on Small Host Countries in Central, Eastern, And Soutb Eastern Europe 31 (World Bank Group, Working Paper, April 2019), http://pubdocs.worldbank.org/en/589991557325278014/FinSAC-BREffects-on-Small-Host-Countries-Europe.pdf [https://perma.cc/XX5J-X9G2].

293. Council Regulation 1024/2013 of 15 October 2013 Conferring Specific Tasks on the European Central Bank Concerning Policies Relating to the Prudential Supervision of Credit Institutions, art. 7, 2013 O.J. (L 287) 63 (201377 (EU). The Member State enters into a close cooperation agreement with the ECB, which is later issued as an ECB decision. Denmark and Sweden are considering joining the Single Supervisory Mechanism. See Denmark Wants in on EU Banking Union, THE LOCAL (April 30, 2015, 11:11 AM), https://www.thelocal.dk/ 20150430/denmark-european-banking-union [https://perma.cc/X4P5-92SF]; See also Simon Johnson, Swedish C. Bank Says Advantages to foining EU Banking Union, ReuTers, (April 23, 2020), https://news.yahoo.com/swedish-c-bank-says-advantages-083236290.html [https:// perma.cc/WER6-UQW8]. Bulgaria is in the process of joining the Eurozone. See also Nikolay Jeliazkov, European Commissioner Vice- President Dombrovskis: Bulgaria May foin Eurozone Three Years After foining ERM II, BUlgarian News AgenCy (July 18, 2018, 10:57 AM), http:// www.bta.bg/en/c/DF/id/1839492 [https://perma.cc/9CF5-LANM].

294. See Press Release, Eur. Cent. Bank, ECB Assumes Responsibility for Banking Supervision, (Nov. 4, 2014), https://www.ecb.europa.eu/press/pr/date/2014/html/pr141104.en.html\#: : text=the \%20European\%20Central\%20Bank\%20(ECB,banks\%20in \%20the\%20uro\%20area [https://perma.cc/Z9ZE-2LG9].

295. Council Regulation 1024/2013, art. 9(1), 2013 O.J. (L 287) 77 (EU).

296. Id. at art. $4(1)(\mathrm{g})$. 
office of a banking group is located within the Eurozone, the ECB serves as the home supervisor. ${ }^{297}$ National supervisors from non-Eurozone jurisdictions continue to serve in that college. ${ }^{298}$ If the head office of the banking group is outside of the Eurozone, the national supervisor in the jurisdiction where the head office is located is the home supervisor of the supervisory college and the ECB represents the Eurozone national supervisors as a host supervisor in such supervisory college. ${ }^{299}$ The national supervisors from the Eurozone may continue to participate as observers, but they defer any decision-making to the ECB. ${ }^{300}$ As a result of the SSM, the $\mathrm{ECB}$ takes on a more influential role in supervisory colleges as it substitutes for any of the nineteen Eurozone supervisors that previously served in such college.

Under the SSM, the ECB exercises its supervisory authority over the largest banks operating in the Eurozone through Joint Supervisory Teams (JSTs), which substitute for the supervisory college of a Eurozone banking group. ${ }^{301}$ The JST is the principal form of cooperation between the ECB and national supervisors of Eurozone members.302 Created for each of the cross-border banking groups supervised by the ECB, a JST consists of ECB supervisory officials and officials from the national supervisors in the jurisdictions where the cross-border banking group operates. ${ }^{303}$ The SSM Regulation states that National Competent Authority (NCA) staff will assist the ECB with "the ongoing day-to-day assessment of a credit institution's situation and related on-site verifications." ${ }^{304}$ The JSTs are multinational teams of supervisors from all Eurozone countries. ${ }^{305}$ They communicate in multiple languages and come from different supervisory cultures. ${ }^{306}$ JSTs vary in size depending on the size and importance of the supervised bank. ${ }^{307}$ An ECB official-the JST coordinator-heads the JST and officials from

297. Id. at art. 4(1)(b).

298. Id. at 67.

299. Id. at art. 17(1).

300. Council Regulation 1024/2013, art. 4(1)(g), 2013 O.J. (L 287) 77 (EU).

301. Foint Supervisory Teams, EUR. CENT. BANK, https://www.bankingsupervision.europa.eu/ banking/approach/jst/html/index.en.html [https://perma.cc/X67U-ZRG6] (last visited Oct. 15, 2020).

302. $I d$.

303. Id.

304. Jens Dammann, The Banking Union: Flawed by Design, 45 GEO. J. INT'L L. 1057, 1089 (2014). National Competent Authorities are the national bank supervisory authorities of an EU Member State, for example, Bafin (Federal Financial Supervisory Authority) in Germany. Id. 305. Single Supervisory Mechanism-Good Start but Further Improvements Needed, EuR. CourT AudiTorS, at 53 (2016), https://www.eca.europa.eu/Lists/News/NEWS1611_18/SR_SSM _EN.pdf [https://perma.cc/HMQ3-GJAU].

306. Id.

307. The ECB assigns the largest banks to five different clusters based on the following factors: the size of the bank, the interconnectedness of the bank, the lack of substitutes available for the services provided by the bank, the cross-jurisdictional activity of the bank, the complexity of the bank, and bank-specific risk factors. $I d$. at 56. Banks in Cluster 1 are the more significant banks with banks in cluster 5 being less significant based on these factors. Id. at 55 . 
the national supervisors also serve on the JST. 308 The nationality of the JST coordinator may not be the same as the country where the home office of the banking group supervised is located. ${ }^{309}$ 'To further ensure independence, the JST coordinator for a particular bank is generally appointed to a three to five year term. ${ }^{310}$

Banks with cross-border operations in the European Union are supervised by a supervisory college or a JST, except for less significant banks where the National Competent Authority supervises the bank. ${ }^{311}$ EU law requires supervisory colleges governing bank operations within the European Union to make specific supervisory decisions and assessments. ${ }^{312}$ The tasks of a supervisory college within the EU are specified by EU banking law, particularly the Capital Requirements Directive ${ }^{313}$ and the Bank Resolution and Recovery Directive. ${ }^{314}$ These tasks include: the adoption of a written cooperation and coordination agreement (WCCA), group risk assessment, group liquidity assessment, joint decision on capital and liquidity, ${ }^{315}$ and joint decision on the assessment of group recovery plans. ${ }^{316}$

EU law, primarily the Capital Requirements Directive, also specifies which NCAs serve on supervisory colleges of cross-border banks operating in the European Union. ${ }^{17}$ NCAs where subsidiaries and significant branches, as defined in EU law, are located generally serve on supervisory colleges in the European Union. ${ }^{318}$ While the Basel Committee standardsthe Minimum Standards and Core Principles-recommended sharing information and risk assessments of international banks, ${ }^{319} \mathrm{EU}$ law has gone

308. See Single Supervisory Mechanism-Good Start but Further Improvements Needed, supra note 305 , at 18 .

309. Guide to Banking Supervision, supra note 272, at 15 . However, in the startup of the SSM, this policy has not always been followed. See Special Report - European Banking Supervision Taking Shape - EBA and its Changing Context, supra note 268, at 58.

310. Special Report - European Banking Supervision Taking Shape - EBA and its Changing Context, supra note 268 , at 59.

311. Guide to Banking Supervision, supra note 272, at 15.

312. Council Directive 2013/36/EU of the European Parliament and of the Council of 26 June 2013 on Access to the Activity of Credit Institutions and the Prudential Supervision of Credit Institutions and Investment Firms, Amending Directive 2002/87/EC and Repealing Directives 2006/48/EC and 2006/49/EC, art. 116, 2013 O.J. (L 176) 398.

313. Id.

314. Council Directive 2014/59/EU of the European Parliament and of the Council of 15 May 2014 Establishing a Framework for the Recovery and Resolution of Credit Institutions and Investment Firms and Amending Council Directive 82/891/EEC, and Directives 2001/24/EC, 2002/47/EC, 2004/25/EC, 2005/56/EC, 2007/36/EC, 2011/35/EU, 2012/30/EU and 2013/36/ EU, and Regulations (EU) No 1093/2010 and (EU) No 648/2012, of the European Parliament and of the Council, art. 18, 25, 30, 2014 O.J. (L 173) 237, 243, 246-47.

315. Council Directive 2013/36/EU, art. 116(1), 2013 O.J. (L 176) 398.

316. Council Directive 2014/59/EU, art. 6(2), 8(2), 2014 OJ. (L 173).

317. Council Directive 2013/36/EU, art. 131, 2013 O.J. (L 176) 398.

318. Council Directive 2013/36/EU, art. 116(6), 2013 O.J. (L 176) 398.

319. See Core Principles for Effective Banking Supervision, supra note 110, at 405; Minimum Standards, supra note 84, at 2. 
further and required supervisory colleges to make these decisions and assessments jointly.320 Within the Eurozone, supervisory colleges are decision-making bodies and issue binding decisions on cross-border banks.

\section{Conclusion}

The development of international financial markets and the resulting increase in international bank failures provided the impetus for supervisory cooperation among bank regulators beginning in the 1970s. Early common supervisory standards were general, non-binding statements of best practice. The Concordat was a general statement regarding supervisory cooperation that did not make clear who was the primary supervisor of an international bank. Does the home supervisor or the host supervisor act in the event of a bank failure? There was no clear statement regarding lender of last resort responsibilities.

The Revised Concordat was a more specific, but nevertheless still general, statement of supervisory cooperation. This statement did establish dual key supervision where both the home supervisor and host supervisor must be satisfied with the other's supervisory capacity and practice or they could restrict the operation of the international bank within their jurisdiction. ${ }^{321}$ The Revised Concordat clearly adopted the principle of consolidated supervision. But it made no statement regarding lender of last resort responsibility.

The Minimum Standards for the Supervision of International Banking Groups was an even more specific statement regarding supervisory cooperation. The standards clearly stated the home supervisor must conduct consolidated supervision of the international bank. ${ }^{322}$ The home supervisor is the primary regulator. ${ }^{323}$ Both home and host supervisor approval are required to open a foreign banking establishment. 324

The Great Recession of 2007-2008 caused multiple reform efforts in international financial regulation. This article has focused on the increased use of supervisory colleges in regulating international banks. Previously, supervisory colleges existed for international banks, but the reform efforts placed a new emphasis on supervisory colleges as tools for supervisory cooperation. The Basel Committee issued general, non-binding statements regarding the operation of supervisory colleges-the 2010 Good Practice Principles and subsequently the 2014 Principles for Effective Supervisory Colleges which provided further detail on the best use of supervisory colleges. ${ }^{325}$

320. Council Directive 2013/36/EU, art. 113, 2013 O.J. (L 176) 398.

321. Revised Concordat, supra note 43, at 903-04.

322. Minimum Standards, supra note 84 , at 3.

323. Id.

324. Id. at 4.

325. See Basel Committee on Banking Supervision, Good Practice Principles on Supervisory Colleges, supra note 161, at 7 . 
EU Member States as members of the Basel Committee influenced these standards. The European Union went beyond the mere typical informationsharing of supervisory colleges and created a bank supervisory legal structure. Based on recommendations in the Lamfalussy Report, the European Union created the Committee of European Bank Supervisors, an advisory body. ${ }^{326}$ After the Great Recession, the Larosière Report recommended the creation of European supervisory authorities, including the European Banking Authority. 327 The EBA had legal powers and the power to mediate disputes between national competent authorities. 328 'This mediation power or any type of dispute resolution mechanism was not present in any of the earlier Basel Committee standards.

After the Eurozone crisis, the European Union created a supranational bank regulator-the Single Supervisory Mechanism within the European Central Bank. ${ }^{329}$ The SSM supervises the largest banks within the Eurozone, created a more uniform supervisory culture for banks operating within the Eurozone and reduced, to a certain degree, national discretion by Member States' national supervisory authorities. ${ }^{330}$ Through joint supervisory teams, the SSM coordinates with national supervisors in the supervision and regulation of these banks. ${ }^{331}$ Because the SSM substitutes for the national supervisors of the nineteen Eurozone members, the membership of supervisory colleges was streamlined and simplified. In addition to the creation of this supranational prudential supervisor, EU law required supervisory colleges to make certain substantive decisions and risk assessments regarding banks operating within the European Union. ${ }^{332}$ The European Union thus created both legal requirements for supervisory cooperation and a supervisory structure to ensure those requirements are fulfilled.

This article illustrates a case study of how soft law on supervisory cooperation over a fifty-year period became binding, hard law in stages within the European Union. General, non-binding statements of an international standard-setting body-the Basel Committee-were the beginning of this process. Bank failures beginning in the $1970 \mathrm{~s}$ and continuing into the $1980 \mathrm{~s}$ and 1990s led to the creation of the Basel Committee and its pronouncements on international standards of supervisory cooperation. ${ }^{333}$ As the international banking system became more global and interconnected, particularly in the European Union,

326. See Lamfalussy et al., supra note 182 , at 19.

327. Larosière et al., supra note 230 , at $52-55$.

328. Council Regulation 1093/2010, art 19(1) 2010 O.J. (L 331) 12, 23.

329. Communication from the Commission to the European Parliament and the Council $A$ Roadmap Towards a Banking Union, supra note 270 , at 4, 6 .

330. Wymeersch, supra note 285, at 13.

331. Foint Supervisory Teams, supra note 301.

332. Council Directive 2013/36/EU, art. 116(1), 2013 O.J. (L 176) 398.

333. History of the Basel Committee, Bank INT'L SETTLEMENTs, https://www.bis.org/bebs/ history.htm [https://perma.cc/NV3L-KF9B] (last visited Oct. 15, 2020). 
structural changes were made to the supervisory system in the European Union and even more so in the Eurozone. ${ }^{334}$ Events over this period, including EU efforts to integrate the financial services market, the Great Recession, and the Eurozone crisis, caused these general statements to become more specific and detailed. ${ }^{335}$ Eventually, the European Union took the further step of incorporating these standards into enforceable EU law (banking directives and regulations) and creating a supranational supervisory authority for banks operating in the Eurozone-the Single Supervisory Mechanism of the European Central Bank-to enforce these regulations and directives and to develop a common supervisory culture. Therefore, spurred by external events over decades, soft law on supervisory cooperation has become enforceable hard law within the European Union. 
